\title{
Predicting trace metal solubility and fractionation in urban soils from isotopic exchangeability.
}

\author{
Mao L.C. ${ }^{1,2}$, Young S.D. ${ }^{* 1}$, Tye A.M. ${ }^{3}$ and Bailey E.H. ${ }^{1}$ \\ ${ }^{1}$ Division of Agricultural and Environmental Sciences, School of Biosciences, University of \\ Nottingham, Sutton Bonington Campus, Loughborough, Leicestershire LE12 5RD, United Kingdom. \\ ${ }^{2}$ School of Environment and Architecture, University of Shanghai for Science and Technology, \\ Shanghai, 200093, China. \\ ${ }^{3}$ British Geological Survey, Nicker Hill, Keyworth, Nottingham, NG12 $5 G G$. \\ *Corresponding Author Tel and email: +44 (0) 115 9516256, scott.young@nottingham.ac.uk
}

\begin{abstract}
Metal-salt amended soils (MA, $n=23$ ), and historically-contaminated urban soils from two English cities (Urban, $n=50$ ), were investigated to assess the effects of soil properties and contaminant source on metal lability and solubility. A stable isotope dilution method, with and without a resin purification step, was used to measure the lability of $\mathrm{Cd}, \mathrm{Cu}, \mathrm{Ni}, \mathrm{Pb}$ and $\mathrm{Zn}$. For all five metals in MA soils, lability (\%E-values) could be reasonably well predicted from soil $\mathrm{pH}$ value with a simple logistic equation. However, there was evidence of continuing time-dependent fixation of $\mathrm{Cd}$ and $\mathrm{Zn}$ in the MA soils, following more than a decade of storage under air-dried conditions, mainly in high $\mathrm{pH}$ soils. All five metals in MA soils remained much more labile than in Urban soils, strongly indicating an effect of contaminant source on metal lability in the latter. Metal solubility was predicted for both sets of soil by the geochemical speciation model WHAM-VII, using E-values as an input variable. For soils with low metal solution concentrations, over-estimation of $\mathrm{Cd}$, $\mathrm{Ni}$ and $\mathrm{Zn}$ solubility was associated with binding to the Fe oxide fraction while accurate prediction of $\mathrm{Cu}$ solubility was dependent on humic acid content. Lead solubility was most poorly described, especially in the Urban soils. Generally, slightly poorer estimation of metal solubility was observed in Urban soils, possibly due to a greater incidence of high $\mathrm{pH}$ values. The use of isotopically exchangeable metal to predict solubility is appropriate both for historically contaminated soils and where amendment with soluble forms of metal is used, as in toxicological trials. However, the major limitation to predicting solubility may lie with the accuracy of model input variables such as humic acid and Fe oxide contents where there is often a reliance on relatively crude analytical estimations of these variables.
\end{abstract}

Capsule:

Trace metal reactivity in urban soils depends on both soil properties and the original source material; the WHAM geochemical model predicts solubility using isotopically exchangeable metal as an input. 


\section{INTRODUCTION}

Accurate assessment of risk from heavy metal contamination of the environment requires consideration of metal 'reactivity' or 'lability' in soils (Fairbrother et al., 1999; Lock and Janssen, 2001). Published literature (Degryse et al., 2004, Tack, 2010, Hammer et al., 2006) generally suggests that the lability of trace metals in soils is the net result of three factors: (i) soil properties, including soil physicochemical characteristics such as pH (e.g. McBride et al., 2006; Bonten et al., 2008) and redox potential (Borch et al., 2010) and the proportions of soil constituents such as Fe/Mn hydroxide and organic matter present (Tipping et al., 2003; Rodrigues et al., 2010); (ii) metal sources, which may vary greatly in their intrinsic metal lability (e.g. Atkinson et al., 2011; Mao et al., 2014) and (iii) soil-metal contact time, because there is a time-dependency to both metal fixation in soils (e.g. Tye et al., 2003; Ma et al., 2006b) and the release of trace metals from contaminant sources in soils (Kaste et al., 2006; Atkinson et al., 2011). Generally, low metal lability is more likely in soils with high $\mathrm{pH}$ values and following long contact times. Recent studies have focused on the concentrations and origins of heavy metals in the urban environment (Manta et al., 2002; Cheng et al., 2014; Wei and Yang, 2010), but the effects on lability arising from characteristics of the original contaminant source are usually difficult to assess (Mao et al., 2014).

A range of techniques have been developed to measure the lability of trace element fractions in soils, among which isotope dilution is perhaps the most appropriate method (Degryse et al., 2009). This approach defines an amount of metal, distributed between the solution and solid phases, which is isotopically exchangeable, known as the E-value or $\mathrm{M}_{\mathrm{E}}$ (Smolders et al., 1999; Young et al., 2000). Measurement is achieved by adding a small 'spike' of an enriched isotope of the analyte of interest into a pre-equilibrated soil suspension and measuring the isotopic abundance of the spike isotope in the separated solution phase. The extent to which the spike isotope has been able to mix with the indigenous soil metal quantifies the 'isotopically exchangeable' metal pool in the soil. The method has been modified to correct for the presence of non-labile metal in sub-micron colloidal particles (SCP-metal) by adding a resin purification step (Lombi et al., 2003). E-values can then be used as input variables to geochemical speciation models, such as WHAM (Windermere Humic Aqueous Model, Tipping et al., 2003) to predict metal fractionation and speciation in the solid and solution phases of soils respectively (Tipping et al., 2003; Shi et al., 2008; Almas et al., 2007; Buekers et al., 2008b; Marzouk et al., 2013b).

The primary aims of this study were to investigate how trace metal lability and solubility are affected by (i) soil properties, (ii) ageing and (iii) variable contamination sources in urban soils. To achieve this, objectives focussed on determination of the isotopically exchangeable fractions of $\mathrm{Cd}, \mathrm{Cu}, \mathrm{Ni}, \mathrm{Pb}$ and $\mathrm{Zn}\left(\mathrm{M}_{\mathrm{E}}\right)$ in two distinct sets of soil samples. These included (i) soils, chosen for their range of land uses and soil properties, that had been incubated with metal nitrate salts $(\mathrm{Cd}, \mathrm{Cu}, \mathrm{Ni}, \mathrm{Pb}$ and $\mathrm{Zn}$ ) for several years and (ii) urban contaminated soils, from Nottingham and Wolverhampton (UK), chosen for their range of metal contaminant concentrations and sources. To reveal the effect of contaminant source, the 
logistical models for describing metal lability with $\mathrm{pH}$ were parameterised. Secondary objectives included: (i) testing for non-labile SCP-metal $(<0.22 \mu \mathrm{m})$ by comparing values of $\mathrm{M}_{\mathrm{E}}$ with equivalent values following a resin cleaning procedure $\left(\mathrm{M}_{\mathrm{Er}}\right)$; (ii) testing for metal fixation in air dried soil stored for more than a decade, (iii) comparing a sequential fractionation scheme with fractionation by isotopic exchangeability and (iv) assessing the performance of the geochemical model, WHAM VII, to predict $\mathrm{Cd}, \mathrm{Cu}, \mathrm{Ni}, \mathrm{Pb}$ and $\mathrm{Zn}$ solubility in both sets of soils.

\section{MATERIAL AND METHODS}

\subsection{Soil sampling}

Two sets of soils were used in this study. The first set comprised 23 metal-amended topsoils (MA soils), from sites with contrasting land uses and parent material, to provide a wide range of soil properties $(\mathrm{pH}$, soil organic matter, mineral (hydr)oxides content and texture). These soils were collected for a previous study of trace metal fixation and solubility (Tye et al., 2003; Tye et al., 2004) and had been amended with metal nitrate salts to the limits prescribed by the UK Sludge Regulations (MAFF, 1993) $(\mathrm{Cd}=3$, $\mathrm{Cu}=135, \mathrm{Ni}=75, \mathrm{~Pb}=300$ and $\mathrm{Zn}=300 \mathrm{mg} \mathrm{kg}^{-1}$ ) before being incubated at $16^{\circ} \mathrm{C}$ and $80 \%$ field capacity (FC) for $\sim 3$ years (Tye et al., 2003), air-dried, and then stored for $\sim 12$ years prior to the current study. The second set (Urban soils) consisted of 50 topsoils collected in the cities of Wolverhampton (WV) and Nottingham (NG), UK. Site selection included consideration of historical and recent industrial and domestic land use and locations included brownfield sites, rail transport sidings, urban roadsides, waste disposal facilities, recreational areas, gardens, urban nature reserves and woodland and parkland areas. Data relating to these soils has been published previously in an investigation of metal speciation and bioavailability in risk assessment (Thornton et al., 2008; Hough et al., 2005).

\subsection{Soil characterization}

Some of the soil properties originally determined were re-measured to identify changes during storage and to provide a more complete input dataset for subsequent modelling (Section 2.6). Soil pH was measured on suspensions ( $1 \mathrm{~g}$ soil: $30 \mathrm{~mL}$ of $\left.0.01 \mathrm{M} \mathrm{Ca}\left(\mathrm{NO}_{3}\right)_{2}\right)$ using a $\mathrm{pH}$ meter with combined $\mathrm{Ag} / \mathrm{AgCl}$ glass electrode (Model pH 209, HANNA Instruments, Bedford, UK). Total organic matter content was estimated using a LECO combustion analyser (Tye et al., 2003) for MA soils. For Urban soils total organic matter content was calculated from the difference between total soil carbon (SC) content measured using an Elemental Analyser (CE Instruments model Flash EA1112) and calibrated using a range of certified soils, and carbonate content determined by manometric assay using the Collins' calcimeter method (Piper, 1954). Alkaline extraction was used to determine humic acid (HA) and fulvic acid (FA) content in all soils. Organic carbon content in HA and FA was measured using a Shimadzu TOC-Vcp analyser. Clay content (\%) was estimated from the soil texture classification provided by Tye et al. (2003) for MA soils. Iron, Al and Mn oxide concentrations were determined following 
Anschutz et al., 1998). Total $\mathrm{Cd}, \mathrm{Cu}, \mathrm{Ni}, \mathrm{Pb}$ and $\mathrm{Zn}$ concentrations in soil were determined following digestion of $200 \mathrm{mg}$ of finely ground soil with $\mathrm{HF}$ (40\% AR), $\mathrm{HNO}_{3}(70 \% \mathrm{TAG}), \mathrm{HClO}_{4}(70 \% \mathrm{AR})$ and $2.5 \mathrm{~mL} \mathrm{H}_{2} \mathrm{O}$ in a block digester (Model A3, Analysco Ltd, Chipping Norton, UK). Iron, $\mathrm{Al}$ and

$111 \mathrm{Mn}$ in DCB extractants and trace metals in acid digests were analysed by Inductively Coupled Plasma112 Mass Spectrometry (ICP-MS; Thermo-Fisher Scientific X-Series ${ }^{\mathrm{II}}$ ) operating in 'collision cell mode' 113 (7\% hydrogen in helium) to reduce polyatomic interferences.

\subsection{Cadmium, $\mathrm{Cu}, \mathrm{Ni}, \mathrm{Zn}$, and Pb lability measured by isotopic dilution (E-value)}

115

116

\section{Sample preparation}

The stable isotopic dilution method used in this study was adapted from Atkinson et al. (2011). Soils were pre-equilibrated in $0.01 \mathrm{M} \mathrm{Ca}\left(\mathrm{NO}_{3}\right)_{2}(1 \mathrm{~g}: 30 \mathrm{~mL})$ on an end-over-end shaker for 3 days; 4 suspensions were made for each soil. An aliquot $(0.4 \mathrm{~mL})$ of enriched stable isotope stock solution (ISOFLEX, San Francisco CA, USA) in $\sim 2 \% \mathrm{HNO}_{3}$, with known isotopic abundances (IA) for ${ }^{108} \mathrm{Cd}$ $(\mathrm{IA}=69.7 \%),{ }^{65} \mathrm{Cu}(\mathrm{IA}=99.0 \%),{ }^{62} \mathrm{Ni}(\mathrm{IA}=98.2 \%),{ }^{204} \mathrm{~Pb}(\mathrm{IA}=98.8 \%)$ and ${ }^{70} \mathrm{Zn}(\mathrm{IA}=92.7 \%)$ was added to two of the suspensions and the other two were used as control samples to derive the natural isotopic abundance of the labile metal. The spike isotopes used were, with the exception of ${ }^{65} \mathrm{Cu}$, chosen because they have relatively low natural isotopic abundance (De Bievre and Barnes, 1985). Therefore, only a small addition to the system was required to produce a significant increase in IA from the background level. To reduce the number of individual operations and to avoid adding different amounts of isotopes to each soil, the samples were classified into several groups according to their soil metal content. The level of isotope tracer to be added was determined from the highest concentration of metal in each group to ensure that the difference in isotopic ratio between the spiked and un-spiked samples was at least $20 \%$. After spiking, the suspensions were shaken for a further 3 days; the solution and solid phases were then separated by centrifugation $(2200 \mathrm{~g})$ and then filtration $(<0.2 \mu \mathrm{m})$. For several Urban soils, where the native and/or spike metal concentrations in $0.01 \mathrm{M} \mathrm{Ca}\left(\mathrm{NO}_{3}\right)_{2}$ suspension were judged to be too low to provide reliable isotopic ratios (Midwood, 2007), a suspending solution of $1 \times 10^{-5} \mathrm{M}$ EDTA was used to shift the labile metal equilibrium in favour of the soil solution while presenting minimal risk of mobilizing non-labile metal, as shown by Atkinson et al., (2011) and Nazif et al., (2015).

\section{ICP-MS settings for measuring isotopic abundances and calculation of E-value}

Isotopic ratios in supernatant solutions were measured by ICP-MS in 'collision cell with kinetic energy discrimination' (CCT-KED) mode to avoid interference from the chlorine dimer $\left({ }^{35} \mathrm{Cl}-{ }^{35} \mathrm{Cl}\right)$, and other polyatomic species, on ${ }^{70} \mathrm{Zn}$ (Malinovsky et al., 2005; Stenberg et al., 2004). Quadrupole dwell times were short to reduce plasma flicker: ${ }^{108} \mathrm{Cd}(10 \mathrm{~ms}),{ }^{111} \mathrm{Cd}(2.5 \mathrm{~ms}),{ }^{63} \mathrm{Cu}(2.5 \mathrm{~ms}),{ }^{65} \mathrm{Cu}(10 \mathrm{~ms}),{ }^{60} \mathrm{Ni}$ (2.5 ms), ${ }^{62} \mathrm{Ni}(10 \mathrm{~ms}),{ }^{204} \mathrm{~Pb}(10 \mathrm{~ms}),{ }^{206} \mathrm{~Pb}(2.5 \mathrm{~ms}),{ }^{207} \mathrm{~Pb}(2.5 \mathrm{~ms}),{ }^{208} \mathrm{~Pb}(2.5 \mathrm{~ms}),{ }^{66} \mathrm{Zn}(2.5 \mathrm{~ms})$ and ${ }^{70} \mathrm{Zn}(10 \mathrm{~ms})$. The isotopes ${ }^{59} \mathrm{Co},{ }^{107} \mathrm{Ag}$ and ${ }^{202} \mathrm{Hg}$ were also measured, as quadrupole settle points (Marzouk et al., 2013a). It is well known that the relative abundance of Pb isotopes varies according to the sources of $\mathrm{Pb}$ present in the soil (Komarek et al., 2008). Therefore, instead of relying on assumed 
relative abundances of naturally occurring isotopes, the apparent isotopic ratio in un-spiked samples (blanks) was also determined for all five elements. To avoid the electron multiplier detector tripping to analogue mode, all the sample solutions were diluted appropriately.

A source of error when analysing stable isotopes is mass discrimination: isotopes with greater mass are measured by ICP-MS with greater sensitivity and so the measured ratio of CPS for two isotopes is not equal to their true isotopic ratio. External mass discrimination correction was therefore applied using a certified isotopic standard reference material (NIST, SRM 981) for Pb and a mix of single ICP-MS calibration standards for $\mathrm{Cd}, \mathrm{Cu}, \mathrm{Ni}$, and $\mathrm{Zn}$. The mixed standard $\left(25 \mu \mathrm{g} \mathrm{L}^{-1}\right)$ was used to calculate a correction factor (K-Factor) (Eq. 1):

$K-$ factor $=\frac{I R}{C R}$

where IR and CR are the true isotopic ratio and the measured ratio of CPS for the isotopic standard respectively. For individual samples, the K-factor for each isotopic ratio (e.g. ${ }^{204} \mathrm{~Pb} /{ }^{208} \mathrm{~Pb},{ }^{206} \mathrm{~Pb} /{ }^{208} \mathrm{~Pb}$, ${ }^{207} \mathrm{~Pb} /{ }^{208} \mathrm{~Pb}$ ) was estimated by linear interpolation between the $\mathrm{K}$-factor measured for standards run at intervals of eight samples.

Concentrations of isotopically exchangeable metal $\left(\mathrm{M}_{\mathrm{E}} ; \mathrm{mg} \mathrm{kg}^{-1}\right)$ were calculated for $\mathrm{Cd}, \mathrm{Cu}, \mathrm{Ni}, \mathrm{Pb}$ and $\mathrm{Zn}$ from Eq. 2 adapted from Gabler et al. (1999):

$M_{E}=\left(\frac{A m_{M s o i l}}{W}\right)\left(\frac{C_{s p k} V_{s p k}}{A m_{M s p k}}\right)\left(\frac{{ }^{s p k} I A_{\text {spike }}-{ }^{b g_{I}} I_{\text {spike }} R_{S S}}{{ }^{b A_{\text {soil }} R_{s S^{-}}{ }^{s p k} I A_{\text {soil }}}}\right)$

where $\mathrm{Am}_{\mathrm{M} \text { soil }}$ and $\mathrm{Am}_{\mathrm{Mspk}}$ are the average atomic masses of $\mathrm{Cd}, \mathrm{Cu}, \mathrm{Ni}, \mathrm{Pb}$ or $\mathrm{Zn}$ in the soils and the spike isotope solution respectively, $\mathrm{W}$ is the weight of the soil $(\mathrm{kg}), \mathrm{C}_{\mathrm{spk}}$ is the gravimetric concentration of the metal in the spike solution, $\mathrm{V}_{\text {spk }}$ is the volume of spike added (L), IA is the isotopic abundance and $\mathrm{R}_{\mathrm{ss}}$ is the ratio of isotopic abundances, spiked (spk): background (bg), for the two isotopes in the spiked soil solution. For comparative purposes, lability is often expressed as a percentage of the total metal content of the soil $\left(\% \mathrm{M}_{\mathrm{E}}\right)$

A 'resin purification' test for the presence of non-labile metal in suspended colloidal particles (SCPmetal; $<0.2 \mu \mathrm{m}$ ), first described by Lombi et al. (2003), was undertaken. Analytical grade Na-Chelex100 resin (Bio-Rad laboratories, $\mathrm{UK}$ ) was converted to the $\mathrm{Ca}^{2+}$ form by equilibrating in $0.5 \mathrm{M} \mathrm{Ca}\left(\mathrm{NO}_{3}\right)_{2}$ for 2 hours. The resin was then washed twice with MilliQ water $(18.2 \mathrm{M} \Omega \mathrm{cm})$ to remove remaining $\mathrm{Na}^{+}$ions. An aliquot of Ca-Chelex resin (c. $100 \mathrm{mg}$ ) was introduced into $10 \mathrm{~mL}$ of filtered $(<0.2 \mu \mathrm{m})$ solution from both spiked and un-spiked soil suspensions. After equilibration for 2 hours, the resin was rinsed with MilliQ water three times to remove colloidal particles. Metals were then eluted from the resin with $0.5 \mathrm{M} \mathrm{HNO}_{3}$ and the measured isotopic ratio used to calculate the labile pool $\left(\mathrm{M}_{\mathrm{Er}} ; \mathrm{mg} \mathrm{kg}^{-1}\right)$. Results were compared with $\mathrm{M}_{\mathrm{E}}$ measured directly on the filtered solution phase to test for the presence of non-labile SCP-metal. 
178 A comparison was made between values of $\mathrm{Cd}_{\mathrm{E}}$ and $\mathrm{Zn}_{\mathrm{E}}$ measured in this study in August and September 2011, and the 'radio-labile' fraction $\left(\mathrm{M}_{\mathrm{E}}{ }^{*}\right)$ measured by Tye et al. (2003) on the same soils in October 1999 - shortly after collection of the Urban soils but following $818 \mathrm{~d}$ incubation at $80 \%$ field capacity in the case of the MA soils. The objective was to investigate possible further aging of $\mathrm{Cd}$ and $\mathrm{Zn}$ in MA and Urban soils following 12 years of soil storage under air dry conditions. In the study of Tye et al., the radio-isotopes ${ }^{109} \mathrm{Cd}$ and ${ }^{65} \mathrm{Zn}$ were used to determine $\mathrm{Cd}_{\mathrm{E}}{ }^{*}$ and $\mathrm{Zn}_{\mathrm{E}}{ }^{*}$.

\subsection{Analysis of soil solution}

185 Elemental concentrations of dissolved major ( $\mathrm{Al}, \mathrm{Ca}, \mathrm{K}, \mathrm{Mg}$ and $\mathrm{Na}$ ) and trace ( $\mathrm{Cd}, \mathrm{Cu}, \mathrm{Ni}, \mathrm{Pb}$ and $\mathrm{Zn}$ ) cations were measured in $0.01 \mathrm{M} \mathrm{Ca}\left(\mathrm{NO}_{3}\right)_{2}$ suspensions with $1 \mathrm{~g}$ soil in $30 \mathrm{~mL}$ solution using ICP-MS, as described in Section 2.2. Dissolved organic carbon (DOC) and inorganic carbon (DIC) were determined in the suspensions using a Shimadzu TOC-Vcp analyser. For modelling purposes, an estimate of FA concentration in solution was made assuming that dissolved organic matter (DOM) contains $50 \% \mathrm{C}$ and that $65 \%$ of DOM consists of active FA (Buekers et al., 2008b; Cheng et al., 2005).

\subsection{Describing lability (\%ME) as a function of soil properties}

192 Two types of empirical model for predicting $\% \mathrm{M}_{\mathrm{E}}$ from measured soil properties were assessed. The first was a multiple linear regression model where the simplicity of the equation allows inclusion of a large number of variables. Values of $\% \mathrm{M}_{\mathrm{E}}$ were correlated with a range of soil characteristics including $\mathrm{pH}, \% \mathrm{SOC}$ \% \%lay, Al, Fe and Mn oxide contents $\left(\mathrm{mg} \mathrm{kg}^{-1}\right)$ and total $\mathrm{Cd}, \mathrm{Cu}, \mathrm{Ni}, \mathrm{Pb}, \mathrm{Zn}$ concentration $\left(\mathrm{M}_{\text {total }} ; \mathrm{mg} \mathrm{kg}^{-1}\right)$. The significance of each variable was determined (Minitab vs 16.2.2) and only those

$\% \mathrm{M}_{\mathrm{E}}=\mathrm{k}_{0}+\mathrm{k}_{1}(\mathrm{pH})+\mathrm{k}_{2}(\% \mathrm{SOC})+\mathrm{k}_{3}(\mathrm{FeOx})+\mathrm{k}_{4}(\mathrm{MnOx})+\mathrm{k}_{5}(\mathrm{AlOx})+\mathrm{k}_{6}(\%$ Clay $)+\mathrm{k}_{7}\left(\mathrm{M}_{\text {total }}\right)$

The second model was a logistic (sigmoid) equation based on the assumption that $\mathrm{pH}$ is likely to be the primary determinant of $\% \mathrm{M}_{\mathrm{E}}$ (Eq. 4). A similar function has been shown to describe trace metal adsorption on soil binding phases (Sinitsyn et al., 2000; Lamy et al., 1993). Metal lability was therefore predicted assuming that $\% \mathrm{M}_{\mathrm{E}}$ was controlled only by $\mathrm{pH}$ and that the $\mathrm{pH}$ at which $50 \%$ of the metal was labile $\left(\mathrm{pH}_{50}\right)$ was metal specific (Eq. 4).

$\% M_{E}=\frac{100}{1+\exp \left[k_{M}\left(p H-p H_{50}\right)\right]}$

In Eq. 4, the 'spreading factor' $\left(\mathrm{k}_{\mathrm{M}}\right)$ controls the slope of the model trend across the pH range and is probably unique to a particular soil-metal combination. Therefore, an attempt was made to refine Eq. 4 by making $\mathrm{k}_{\mathrm{M}}$ a function of other soil characteristics (S) describing the role of likely metal adsorbents (e.g. \%SOC, metal oxide concentration and clay content); a power function (n) was added because it achieved a better fit to the data in practice (Eq. 5). 
$211 \% M_{E}=\frac{100}{1+\exp \left[k_{M} S^{n}\left(p H-p H_{50}\right)\right]}$

212 A further simplification was to combine the measured oxide phases into a single variable, allowing for 213 differences in the molecular weight for $\mathrm{Al}_{2} \mathrm{O}_{3}, \mathrm{Fe}_{2} \mathrm{O}_{3} \cdot \mathrm{H}_{2} \mathrm{O}$ and $\mathrm{MnO}_{2}$, resulting in three variables 214 (\%SOC, mineral (hydr)oxides and clay). Only one of the three variables was assumed to control the 215 spread of \% $\mathrm{M}_{\mathrm{E}}$ values with $\mathrm{pH}$ (Eq. 5) for each metal. The constants in Equations 4 and 5 were

216 optimized, using the Solver function in Microsoft Excel, to assess the performance of each model.

$217 \quad 2.6 \quad$ Predicting trace metal solubility and speciation by WHAM-VII

218 The geochemical speciation model WHAM-VII was used to predict $\mathrm{Cd}, \mathrm{Cu}, \mathrm{Ni}, \mathrm{Pb}$ and $\mathrm{Zn}$ 219 concentration in the solution phase of soil suspensions. Measured values of $\mathrm{M}_{\mathrm{E}}$ were used as inputs to 220 WHAM, representing the total reactive trace metal fraction in the soil suspensions. The modelled metal 221 concentration in solution was compared with measured values to assess the model performance. 222 Speciation in solution and fractionation in the soil solid phase were derived from the model output. 223 Model parameters and variables are listed in Appendix 1. 


\section{RESULTS}

225

226

227

228

229

230

231

232

233

234

235

236

237

238

239

240

241

242

243

244

245

246

247

248

249

250

251

252

253

254

255

256

257

258

259

260

\subsection{Soil characteristics}

Full details of soil properties for the MA and Urban soils are provided as supplementary material (Appendices 2\&3). Soil $\mathrm{pH}$ values covered a wide range, from $<4$ to $\sim 8$; the Urban soils were slightly more alkaline with $60 \%$ of $\mathrm{pH}$ values $>6.0$. All the soils can be categorized as mineral soils $(\% \mathrm{SOC}<$ $20 \%$ ) with two possible exceptions; Urban soils with $20.5 \%$ and $25.1 \%$ SOC, one sampled in a public park and the other near a railway line, both had evidence of coal in the soil. Urban soils from brownfield sites typically had the lowest \%SOC (Appendix 2). Iron oxide content (FeOx) in both sets covered a wide range of values (5.4 - $\left.43 \mathrm{~g} \mathrm{~kg}^{-1}\right)$; concentrations of Mn oxides (MnOx) were much lower than $\mathrm{FeOx}\left(0.16-3.01 \mathrm{~g} \mathrm{~kg}^{-1}\right)$, but the two variables were strongly correlated $(\mathrm{p}<0.01)$. Iron oxides strongly adsorb trace metals at neutral and high $\mathrm{pH}$ values (Tack, 2010) whereas Mn oxides are more important at lower pH values due to their lower pzc (Dong et al., 2003; Trivedi and Axe, 2001). For the MA soils, uniformly amended with five trace metals, there was a relatively small variation in total metal concentration resulting from native soil metal content (Tye et al., 2003; Tye et al., 2004). Total metal concentrations in the Urban soils covered a much wider range as a consequence of historical contamination. Some individual metal concentrations in Urban soils were strongly correlated implying contamination from the same source ( $\mathrm{p}$-values $<0.05$ ). Copper, $\mathrm{Ni}, \mathrm{Pb}$ and $\mathrm{Zn}$ concentrations were positively, but weakly, correlated with \%SOC $\left(\mathrm{r}_{\mathrm{Cu}}=0.36, \mathrm{r}_{\mathrm{Ni}}=0.40, \mathrm{r}_{\mathrm{Pb}}=0.45, \mathrm{r}_{\mathrm{Zn}}=0.43,\right), \mathrm{FeOx}\left(\mathrm{r}_{\mathrm{Cu}}=0.47\right.$, $\left.\mathrm{r}_{\mathrm{Ni}}=0.41, \mathrm{r}_{\mathrm{Pb}}=0.37, \mathrm{r}_{\mathrm{Zn}}=0.43\right)$ and $\mathrm{MnOx}\left(\mathrm{r}_{\mathrm{Cu}}=0.48, \mathrm{r}_{\mathrm{Ni}}=0.39, \mathrm{r}_{\mathrm{Pb}}=0.32, \mathrm{r}_{\mathrm{Zn}}=0.38\right)$ possibly as a result of their accumulation in soils with strong binding phases (Rieuwerts et al., 2006; Zimdahl and Skogerboe, 1977). Cadmium concentration was less affected by soil properties, only showing a very weak correlation with $\mathrm{AlOx}\left(\mathrm{r}_{\mathrm{Cd}}=0.34\right)$.

\subsection{Measured metal lability in soils}

Values of $\% \mathrm{M}_{\mathrm{E}}$ for $\mathrm{Cd}, \mathrm{Cu}, \mathrm{Ni}, \mathrm{Pb}$ and $\mathrm{Zn}$ are shown in Fig. 1. For Urban soils the average $\% \mathrm{M}_{\mathrm{E}}$ values were $47.2 \%(\mathrm{Cd}), 20.5 \%(\mathrm{Cu}), 6.28 \%(\mathrm{Ni}), 21.1 \%(\mathrm{~Pb})$ and $18.1 \%(\mathrm{Zn})$ emphasising the need to consider metal lability (i.e. $\mathrm{M}_{\mathrm{E}}, \mathrm{mg} \mathrm{kg}^{-1}$ ), rather than just total soil metal content, when assessing risk and mobility in brownfield sites. Values of metal lability in the MA soils were significantly greater than in the Urban soils with average $\% \mathrm{M}_{\mathrm{E}}$ values of $74.4 \%(\mathrm{Cd}), 48.7 \%(\mathrm{Cu}), 36.2 \%(\mathrm{Ni}), 54.1 \%(\mathrm{~Pb})$ and $41.5 \%$ (Zn) despite three years incubation of MA soils at $80 \%$ field capacity and a further 12 years of storage under air dry conditions. In both sets of soils, the relative lability of the five metals followed the same sequence $(\mathrm{Cd}>\mathrm{Pb} \geq \mathrm{Cu}>\mathrm{Zn}>\mathrm{Ni})$.

The presence of a non-labile fraction of metal in suspended colloidal particles (SCP-metal) in the submicron filtered $(<0.22 \mu \mathrm{m})$ supernatant solutions from the soil suspensions used to measure $\mathrm{M}_{\mathrm{E}}$ values was investigated by comparing $\mathrm{M}_{\mathrm{E}}$ and $\mathrm{M}_{\mathrm{Er}}$ (Appendix 3). For most of the soils, SCP-metal had only a very small effect on measured E-values. There was a strong correlation between $\% \mathrm{M}_{\mathrm{E}}$ and $\% \mathrm{M}_{\mathrm{Er}}$ and an average difference of less than $2 \%$ for all five metals; a significant difference was only observed 
for $\mathrm{Cu}$ in the soils investigated. The ratio of $\mathrm{Cu}_{\mathrm{E}}: \mathrm{Cu}_{\mathrm{Er}}$ against soil $\mathrm{pH}$ and $\% \mathrm{Cu}_{\mathrm{E}}$ (Fig. 2a \& 2b) clearly suggests the presence of SCP-Cu, despite filtration to $<0.22 \mu \mathrm{m}$, especially at low levels of $\% \mathrm{M}_{\mathrm{E}}$ and high $\mathrm{pH}$ values in the Urban soils.

\subsection{Predicting metal lability from soil properties}

The effects of soil properties on values of $\% \mathrm{M}_{\mathrm{E}}$ were described in two ways: a multiple-regression model, which has the advantage of being able to include many variables, and a simple logistic model with soil $\mathrm{pH}$ as the primary determining factor.

In the current study, seven variables were available to predict values of $\% \mathrm{M}_{\mathrm{E}}$ from Eq. 3. Metal lability in the Urban soils is likely to have been affected by factors other than soil properties, especially metal source characteristics. Therefore, Eq. 3 was parameterized using data from the MA soils only in which the added metal was from a single, initially dissolved, source. The goodness of fitting was evaluated from the values of RSD and correlation co-efficient (r). A good level of prediction was achieved for Cd $(\mathrm{r}=0.92, \mathrm{RSD}=6.3)$, Ni $(\mathrm{r}=0.97, \mathrm{RSD}=5.85)$ and $\mathrm{Zn}(\mathrm{r}=0.95, \mathrm{RSD}=7.7)$, but $\mathrm{Cu}$ and $\mathrm{Pb}$ were less successfully modelled, with correlation co-efficient equals to 0.83 and 0.85 respectively. Soil $\mathrm{pH}$ was negatively correlated with $\% \mathrm{M}_{\mathrm{E}}$ for all five metals and accounted for the largest proportion of the total variance in $\% \mathrm{M}_{\mathrm{E}}$ in the MA soils: $63.2 \%, 25.5 \%, 73.1 \%, 53.3 \%$ and $66.1 \%$, for $\mathrm{Cd}, \mathrm{Cu}, \mathrm{Ni}, \mathrm{Pb}$ and $\mathrm{Zn}$ respectively. The optimized constants, RSD values and correlation co-efficients (r) are summarized in Appendix 4.

Although linear regression modelling can provide reasonable predictions of metal lability where $\% \mathrm{M}_{\mathrm{E}}$ is largely a function of soil characteristics and a single contaminant source predominates, as in the MA soils, the application of this model is limited to the range of data used to parameterise the model. Extending 'prediction' of lability outside this range can result in physically impossible outcomes in which modelled values of $\% \mathrm{M}_{\mathrm{E}}$ may be negative, or $>100 \%$. By contrast, a sigmoidal model (Eq. 4) offers more realistic boundaries to model outcomes $\left(\% \mathrm{M}_{\mathrm{E}}=0 \sim 100 \%\right)$. The sequence of optimized $\mathrm{pH}_{50}$ values was $\mathrm{Cd}>\mathrm{Pb}>\mathrm{Cu}>\mathrm{Zn}>\mathrm{Ni}$, and covered nearly three $\mathrm{pH}$ units, in agreement with the expected order of metal lability. The exponential factor $\mathrm{k}_{\mathrm{M}}$ is related to the range of $\mathrm{pH}$ values over which the major change in $\% \mathrm{M}_{\mathrm{E}}$ occurs. Inclusion of each of the adsorption phases (OM, oxides, and clay) was then used to try and refine prediction of \% $\mathrm{M}_{\mathrm{E}}$ according to Eq. 5. For $\mathrm{Cd}, \mathrm{Ni}$ and $\mathrm{Zn}$, the best prediction, lowest RSD and highest value of r, was achieved by including total oxide content within Eq. 5 (S value) to control the spread of predicted $\% \mathrm{M}_{\mathrm{E}}$ values as a function of $\mathrm{pH}$. For $\mathrm{Cu}$ and $\mathrm{Pb}$, including total oxide content also improved prediction of $\% \mathrm{M}_{\mathrm{E}}$, but the lowest RSD was obtained by including clay and organic matter content respectively. Copper produced the lowest $\mathrm{k}_{\mathrm{M}}$ value $(0.16)$ and so only gradually undergoes transition from labile to a fixed state over a relatively large range of $\mathrm{pH}$ values, whereas $\mathrm{Ni}$ and $\mathrm{Zn}$ were labile over a more restricted range of $\mathrm{pH}$ values with $\mathrm{k}_{\mathrm{M}}$ values equal to 0.76 and 0.72 respectively. The optimized values of $\mathrm{pH}_{50}$ and the exponential constant $\mathrm{k}_{\mathrm{M}}$ in $\mathbf{E q .} \mathbf{4} \boldsymbol{\&} \mathbf{5}$, together with the results of modelling for the MA soils are shown in Appendix 5. 


\subsection{Metal lability in MA and Urban soils solely as a function of soil pH}

298 Measured values of $\% \mathrm{M}_{\mathrm{E}}$ for $\mathrm{Cd}, \mathrm{Cu}, \mathrm{Ni}, \mathrm{Pb}$ and $\mathrm{Zn}$ in $\mathrm{MA}$ and Urban soils, as a function of $\mathrm{pH}$ value, 299 are shown in Fig. 3 with model lines derived from Eq. 4. In the MA soils, for all five metals, there was no obvious bias in model prediction across the $\mathrm{pH}$ range. Measured values of $\mathrm{Cu}$ lability were only weakly correlated with $\mathrm{pH}$. Although $\mathrm{Cd}$ and $\mathrm{Pb}$ also showed a restricted range of $\% \mathrm{M}_{\mathrm{E}}$ values, lability exceeded $90 \%$ and $80 \%$, respectively, below $\mathrm{pH}$ 4.0. Zinc and $\mathrm{Ni}$ in the MA soils both showed substantially greater variation in $\% \mathrm{M}_{\mathrm{E}}$ with $\mathrm{pH}$ compared to the other three metals. Only small and nonsignificant differences between predicted values of \% $\mathrm{M}_{\mathrm{E}}$ were achieved by substituting Eq. 5 for Eq. 4 ( $p>0.05)$ which implies no advantage in considering an effect of geocolloidal adsorption phase in the sigmoidal equation. The values of $\mathrm{pH}_{50}$ optimized using Eq. 4 were very similar to those for Eq. $\mathbf{5}$ and followed the observed sequence of relative metal lability in soils (Appendix 5). The measured values for the Urban soils are shown for comparison with the MA soils in Fig. 3. Soil pH affected metal lability in the Urban soils with a trend qualitatively similar to that of the MA soils but $\% \mathrm{M}_{\mathrm{E}}$ values were greatly over-predicted by the model (Eq. 4 parameterised using the MA soils) in all cases. proportion (\%) of the modelled E-value ( $\left.\% \Delta \mathrm{M}_{\mathrm{E}}\right)$; the model being parameterized solely from the MA soils for each element. No correlation between $\% \Delta \mathrm{M}_{\mathrm{E}}$ and $\mathrm{pH}$ or $\% \mathrm{C}$ was observed with the exception of $\mathrm{Pb}$ where a trend with $\mathrm{pH}$ was apparent $(\mathrm{r}=0.602)$ suggesting either a $\mathrm{pH}$ effect on the source of $\mathrm{Pb}$ or a continuing effect of soil-metal contact time (greater for the Urban soils). Thus, overestimation of $\% \mathrm{M}_{\mathrm{E}}$ values for $\mathrm{Pb}$ was greater for soils with high $\mathrm{pH}$ and low metal lability.

\subsection{Changes in Cd and Zn lability in air dried soils during storage}

For the MA soils, a paired t-test showed that the difference between $\mathrm{M}_{\mathrm{E}}$ and $\mathrm{M}_{\mathrm{E}}{ }^{*}$ measured using radioisotopes by Tye et al. (2003) was significant for $\mathrm{Zn}(\mathrm{p}=0.007)$, but not for $\mathrm{Cd}(\mathrm{p}=0.416)$. However, for the Urban soils, there was a significant difference for both $\mathrm{Zn}$ and $\mathrm{Cd}(\mathrm{p}<0.001)$ with, generally, $\% \mathrm{M}_{\mathrm{E}} *>\% \mathrm{M}_{\mathrm{E}}\left(\mathbf{F i g}\right.$. 4a). It is notable, for example, that the difference between $\mathrm{M}_{\mathrm{E}}$ and $\mathrm{M}_{\mathrm{E}}{ }^{*}$ was more pronounced in high pH soils than in acidic soils (Fig. 4b). However, only a very small difference between $\mathrm{M}_{\mathrm{E}}$ and $\mathrm{M}_{\mathrm{E}}{ }^{*}$ was observed in $\mathrm{MA}$ soils; the average ratio $\mathrm{M}_{\mathrm{E}}: \mathrm{M}_{\mathrm{E}}$ * was 0.93 and 1.00 for $\mathrm{Zn}$ and $\mathrm{Cd}$ respectively. In contrast, for the Urban soils the ratios were 0.71 and 0.69 for $\mathrm{Zn}$ and $\mathrm{Cd}$.

\subsection{WHAM-VII prediction of metal solubility and fractionation}

327 The ability of the geochemical speciation model, WHAM-VII, to predict $\mathrm{Cd}, \mathrm{Cu}, \mathrm{Ni}, \mathrm{Pb}$ and $\mathrm{Zn}$ concentration in solution is shown in Fig. 5 as modelled against measured solubility on a $-\log _{10}$ scale $\left(\mathrm{pM}_{\text {soln }}\right)$. Values of $\mathrm{M}_{\mathrm{E}}$ were input to the model to represent the reactive metal pool in the soil suspensions (Appendix 1). Overall WHAM-VII predicted trace metal solubility reasonably well for both sets of soils. The values of RSD were less than 1 ( $\mathrm{pM}_{\text {soln }}$ unit) for all five metals although the 
average absolute bias $\left(\Delta \mathrm{p}\left(\mathrm{M}_{\text {soln }}\right)\right)$ differed between metals. Summary of model outcomes comparing the measured and the predicted are provided in the Appendix 6.

334

Predictions of $\mathrm{Cu}, \mathrm{Ni}, \mathrm{Cd}$ and $\mathrm{Zn}$ solubility were only slightly better for MA soils than for the Urban soils but the difference for $\mathrm{Pb}$ was greater: $\mathrm{r}$ values for $\mathrm{Pb}$ were 0.96 and 0.78 for MA and Urban soils respectively. Among the five metals, the model gave the best prediction for $\mathrm{Cd}$ and $\mathrm{Ni}$ with relatively low scatter around the 1:1 line ( $\mathrm{RSD}=0.51$ and 0.63 respectively) and a high correlation coefficient ( $\mathrm{r}$ $=0.94$ for both metals). The high RSD value for $\mathrm{Zn}(0.83)$ occurred because the model substantially overestimated the solution concentration for several Urban soils with high $\mathrm{pH}$ values (6.93 to 8.08) and very low $\mathrm{Zn}$ concentrations in solution. Prediction of $\mathrm{Cu}$ solubility was reasonably good $(\mathrm{RSD}=0.45$; $\mathrm{r}=0.74$ ) but with some Urban soil outliers. Lead solubility was most poorly predicted by WHAM-VII ( $\mathrm{RSD}=0.64 ; \mathrm{r}=0.85$ ). However, splitting the $\mathrm{Pb}$ dataset between MA and Urban soils, it was clear that, although there was less average bias compared to the other metals, the poor correlation coefficient and large $\mathrm{RSD}$ value was due to the Urban soils $(\mathrm{RSD}=0.73, \mathrm{r}=0.78, \Delta \mathrm{pPb}$ soln $=-0.08$ ), whereas solubility for the MA soils was more accurately predicted although with very slightly greater bias $(\mathrm{RSD}=0.35, \mathrm{r}$ $\left.=0.96, \Delta \mathrm{pPb}_{\text {soln }}=0.11\right)$.

Trace metal fractionation in the solid phase is provided by WHAM-VII as an output. Therefore, metal adsorption on different binding phases was investigated by interrogation of the WHAM-VII output data to determine whether particularly large deviations between measured and predicted metal solubility were associated with predominant sorption on particular binding phases. Average fractionation was modelled using WHAM-VII and includes six particulate geocolloidal fractions and a single pool for the solution phase, including 'colloidal' (dissolved) fulvic acid. Figure 6 illustrates the average proportions of labile $\mathrm{Cd}, \mathrm{Cu}, \mathrm{Ni}, \mathrm{Pb}$ and $\mathrm{Zn}$ predicted to be held in different soil phases alongside with changes in metal lability as a function of soil $\mathrm{pH}$ for both MA and Urban soils, as a combined dataset. For all five metals, Figure 6 suggests that the relative importance of Fe-oxides for metal binding increases with $\mathrm{pH}$, whilst that of organic matter (HA and FA) decreases. The WHAM model predicted that, on average, $96 \%$ of the $\mathrm{Pb}$ was adsorbed on $\mathrm{Fe}$ and Mn oxides for the MA and Urban soils; Mn oxides were more important below $\mathrm{pH}$ 6.5. By contrast, organic matter was most important for $\mathrm{Cu}$ across the $\mathrm{pH}$ range studied. Non-specific adsorption of $\mathrm{Cd}, \mathrm{Ni}$ and $\mathrm{Zn}$ on clay was only significant in soils with very low $\mathrm{pH}$ values ( $\mathrm{pH} 3.5-4.5)$ and low organic matter contents - less than $2.3 \%, 2.4 \%$ and $2.1 \%$ respectively.

Various factors may affect WHAM model performance in predicting metal solubility including soil $\mathrm{pH}$ and solid binding phase. The influence of soil $\mathrm{pH}$ value on model performance was statistically significant for $\mathrm{Cd}, \mathrm{Cu}, \mathrm{Ni}$ and $\mathrm{Zn}(\mathrm{p}<0.01)$, but not for $\mathrm{Pb}$. Overestimation of metal solubility (log scale) increased with soil $\mathrm{pH}$ to give a positive correlation coefficient between $\Delta \mathrm{pM}_{\text {soln }}$ (i.e. bias between the predicted and measured solubility by WHAM on -log scale) and $\mathrm{pH}$. For $\mathrm{Cd}, \mathrm{Ni}$ and $\mathrm{Zn}$, the bias $\left(\Delta \mathrm{pM}_{\text {soln }}\right)$ observed seemed to be mainly associated with the (modelled) proportion of labile metal bound to Fe oxides - especially for $\mathrm{Cd}$ and $\mathrm{Zn}$ in the high $\mathrm{pH}$ range (positive correlation coefficient). In the 
case of $\mathrm{Cu}$, bias was affected by $\mathrm{Cu}$ binding to particulate $\mathrm{Mn}$ oxides, and HA and colloidal (solution phase) FA. There was less over-prediction of solubility with increase in the proportion of $\mathrm{Cu}$ bound with $\mathrm{HA}$ and greater over-prediction with binding to colloidal FA-Cu. Prediction bias for $\mathrm{Pb}$ was relatively unaffected by soil $\mathrm{pH}$ or by the proportion bound to either Fe or Mn oxides; the range of bias was greater for the Urban soils. Correlation (r) between $\Delta \mathrm{pM}_{\text {soln }}$ and soil $\mathrm{pH}$ or percentage binding with an important particulate phase ( $\mathrm{FeOx}, \mathrm{MnOx}, \mathrm{AlOx}, \mathrm{HA})$ or colloidal (dissolved) phase (FA) are presented in Appendix 7.

\section{DISCUSSION}

\subsection{The effect of soil properties and metal source on metal lability}

Greater metal lability in the MA soils (Fig. 1) may partly reflect different soil-metal contact times for the two soil datasets, but it seems very likely that the characteristics of the original metal source are also responsible for lowering the lability in Urban soils. A similar conclusion regarding Cd lability in field contaminated soils was also made by Degryse et al. (2004) comparing radio-labile Cd in soils sampled adjacent to a smelter and 'metal salt incubated soils' but with a much shorter period of incubation.

The relative lability of the five metals in both MA and Urban soils followed the sequence $\mathrm{Cd}>\mathrm{Pb} \geq$ $\mathrm{Cu}>\mathrm{Zn}>\mathrm{Ni}$ which agrees with the observations of Gabler et al., (2007) who measured the lability of these five metals on 115 unpolluted soil samples using a stable isotope dilution approach. In the MA soils, where metal ions were originally added in solution, the difference in lability of the five metals only partly reflects their expected rates of fixation into soil constituents, based on a negative correlation with ionic radius, i.e. $\mathrm{Ni} \geq \mathrm{Cu}>\mathrm{Zn}>\mathrm{Cd} \sim \mathrm{Pb}$ (Degryse et al., 2009; Degryse et al., 2007). The relatively larger proportion of $\mathrm{Zn}$ and $\mathrm{Ni}$ fixed may have been due to substitution for $\mathrm{Fe}$ in oxyhydroxides (Buekers et al., 2008a; Manceau et al., 2000), a mechanism which is less likely for larger ions such as $\mathrm{Cd}$ and $\mathrm{Pb}$ (Buekers et al., 2008a; $\mathrm{Xu}$ et al., 2006). However, the lower lability of $\mathrm{Pb}$ compared to $\mathrm{Cd}$ may be due to $\mathrm{Pb}$ precipitation as pyromorphite in phosphate-rich soils (Dermatas et al., 2008). Copper is predominantly bound with organic matter which may result in a slightly higher lability compared to Zn sorbed within Fe oxides.

For Ni and Zn, a smaller range of lability was seen in the Urban soils than in the MA soils. This may be counter to expectation because the Urban soils had a larger range of metal contaminant sources and the range of soil $\mathrm{pH}$ values (a major determinant of $\% \mathrm{M}_{\mathrm{E}}$ ) in the $\mathrm{MA}$ and Urban soils were broadly similar (Appendix 2). However, the lower lability of metal sources in the Urban soils also probably acts to limit the range of $\% \mathrm{M}_{\mathrm{E}}$ values in comparison with the $\mathrm{MA}$ soils. A restricted range of low $\% \mathrm{M}_{\mathrm{E}}$ values have also been reported for $\mathrm{Pb}$ in calcareous minespoils soils (Degryse et al., 2004; Marzouk et al., 2013a) and for $\mathrm{Cd}$ and $\mathrm{Zn}$ in soils contaminated with smelter wastes (Degryse et al., 2004). However, the greater lability of $\mathrm{Cd}$ in the Urban soils, relative to other metals, does not necessarily indicate that 
the original source of $\mathrm{Cd}$ was more soluble. It has been shown that $\mathrm{Cd}$ and $\mathrm{Zn}$ added to soil in identical (isomorphically substituted) forms (e.g. sphalerite) nevertheless end up with quite different labilities following prolonged exposure to soil processes (Marzouk et al., 2013a; Degryse et al., 2004).

\subsection{Prediction of metal lability}

408 Poor prediction of $\% \mathrm{M}_{\mathrm{E}}$ for $\mathrm{Cu}$ and $\mathrm{Pb}$ compared to $\mathrm{Cd}$, $\mathrm{Ni}$ and $\mathrm{Zn}$ (Appendix 4) may arise from several 409 factors. It is widely recognised that adsorption on humus dominates $\mathrm{Cu}$ dynamics in soils (Weng et al., $4102001)$ but no significant correlation was found between $\mathrm{Cu}$ lability and \% $\mathrm{SOC}$ in this study $(\mathrm{p}>0.05)$.

411 Another possible explanation is a failure to include factors which might promote strong $\mathrm{Cu}$ binding 412 phases in the model, such as sulphide content (Du Laing et al., 2009). In some soils Pb is likely to 413 precipitate in non-labile mineral forms such as chloropyromorphite $\left(\mathrm{Pb}_{5}\left(\mathrm{PO}_{4}\right)_{3} \mathrm{Cl}\right)$ (Lang and 414 Kaupenjohann, 2003); fractionation of $\mathrm{Pb}$ in soils is generally less well described by current 415 geochemical models (Gustafsson et al., 2011).

416 The importance of $\mathrm{pH}$ as a predictor of lability (Appendix 4) is in agreement with previous studies 417 (Rieuwerts et al., 2006; Marzouk et al, 2013b). Stronger adsorption of metals is certainly expected with 418 increasing $\mathrm{pH}$, partly due to the increase in negative charge on all adsorption surfaces. Metal fixation is 419 not necessarily linked directly to strength of adsorption, but it seems reasonable to assume that factors 420 that increase adsorption strength will also reduce isotopic exchangeability. Other processes may also 421 explain the influence of $\mathrm{pH}$ on lability, including preferential adsorption of metal hydroxide complexes 422 (Basta and Tabatabai, 1992) and precipitation as carbonate phases, (e.g. Gambrell, 1994; Charlatchka and Cambier, 2000). In calcareous soils, diffusion into carbonate minerals (Hamon et al., 2002; Collins et al., 2003; Buekers et al., 2007; Ahmed et al., 2008), or surface precipitation reactions (Ma et al., 2006b; Nazif et al, 2015) are important. The significance of individual soil properties in predicting $\% \mathrm{M}_{\mathrm{E}}$ was metal-specific; a positive coefficient (Eq. 3) may suggest that the adsorbent holds labile metal and a negative coefficient may indicate a source of metal fixation. Thus the addition of $\mathrm{FeOx}$ improved the prediction for $\mathrm{Ni}$ and $\mathrm{Zn}$ possibly suggesting that an important mechanism for metal fixation is diffusion into Fe oxide micropores (Jacquat et al., 2009; Manceau et al., 2000; Degryse et al., 2011). Although MnOx was correlated with the lability of all five metals (Appendix 4), it explained $\leq 0.4 \%$ of total variance in predicting $\% \mathrm{M}_{\mathrm{E}}$ for $\mathrm{Cd}, \mathrm{Ni}$ and $\mathrm{Zn}$. For $\mathrm{Cu}$ and $\mathrm{Pb}, \mathrm{MnOx}$ was more important, accounting for 4.8 and $8.2 \%$ of the total variance in $\% \mathrm{M}_{\mathrm{E}}$ with a negative coefficient, which is in agreement with previous studies (Bonten et al., 2008; Weng et al., 2001). The contribution from clay content was extremely limited; only a very small proportion of 'isotopically labile' trace metal ions are normally exchangeable with a neutral alkali-earth salt (Nakhone and Young, 1993). The correlation with clay content may reflect a general association with soil mineral geocolloid content, rather than implying that $\mathrm{Zn}$ and $\mathrm{Ni}$ are fixed within alumino-silicate clay minerals. Nevertheless, specific adsorption of $\mathrm{Zn}$ within hydroxyl-interlayered clays in acidic soils has been demonstrated by Degryse et al. (2011). Finally, there was a negative correlation between total $\mathrm{Cd}, \mathrm{Ni}$ amd $\mathrm{Zn}$ and content and 
values of $\% \mathrm{M}_{\mathrm{E}}$, probably because the larger content of native metal in the Urban soils (especially $\mathrm{Zn}$ ) was less labile than the (fixed amount of) metal ions added as soluble salts to the MA soils.

The logistic model performance was generally slightly poorer than the fit achieved with multiple linear regression (Appendix 4 and 5). However, Eq. 4 has parameters $\left(\mathrm{pH}_{50} ; \mathrm{k}_{\mathrm{M}}\right)$ that are more clearly related to the mechanisms that control trace metal lability and provides extrapolative predictions that remain realistic. Therefore, the simple logistic equation, expressing $\% \mathrm{M}_{\mathrm{E}}$ solely as a function of $\mathrm{pH}$, is perhaps a more robust model for predicting metal lability solely and more useful than regression coefficients for comparative purposes.

Over-prediction of $\% \mathrm{M}_{\mathrm{E}}$ values in the Urban soils compared to the MA soils probably reflects the characteristics of the contaminant source on metal lability. This conclusion is further supported in Fig. 3 by the greater scatter of $\% \mathrm{M}_{\mathrm{E}}$ values for the Urban soils seen for $\mathrm{Cu}$ and $\mathrm{Cd}$ and perhaps also the flatter trend with $\mathrm{pH}$ seen for $\mathrm{Ni}$ and $\mathrm{Zn}$ in Urban soils suggesting a primary mineral source less affected by $\mathrm{pH}$-dependent adsorption strength. In the Urban soils set, more than half of the high $\mathrm{pH}$ soils $(>6.5)$ were associated with old industrial sites, i.e. brownfield, wasteland, etc. (Appendix 2), where metals probably entered the soils in a relatively non-soluble form. Secondary formation of poorly soluble minerals in calcareous soils (Degryse, et al., 2009) or Pb minerals (e.g. cerussite or chloropyromorphite) would also contribute to the trend seen. For example, the average measured lability of $\mathrm{Pb}$ in two phosphate-rich sewage farm soils (NG14 \& NG15, 13.8\%) was much less than that predicted by the MA-parameterized model (50.0\%) suggesting precipitation of $\mathrm{Pb}$ phosphate minerals either in the soil or during the processing of the sewage sludge. However, it was difficult to identify any specific effects of historical or current land use on lability as, for example, soils from 'brownfield sites' produced values of $\% \mathrm{M}_{\mathrm{E}}$ for $\mathrm{Cu}$ ranging from 5.6\% - 30.5\% (NG19 and NG18, Appendix 2).

No effect of $\mathrm{pH}$ on $\% \Delta \mathrm{M}_{\mathrm{E}}$ was identified for $\mathrm{Ni}$ or $\mathrm{Zn}$. A potential explanation is that $\mathrm{Ni}$ in these soils may be mostly attributable to parent material; this is supported by the low total Ni concentrations found (mean $=38.5 \mathrm{mg} \mathrm{kg}^{-1} ; \mathrm{SD}=18.4 \mathrm{mg} \mathrm{kg}^{-1}$ ). Only two soils had substantially higher Ni concentrations (Fig. 3). These were both from a sewage farm (NG14 and NG15) and had the highest values of $\% \mathrm{Ni}_{\mathrm{E}}$ (34.4\% and $42.9 \%$, respectively), suggesting that Ni lability in the sludge was high and that the soilcontaminant interaction was closer to the behaviour seen in the MA soils. It has been suggested previously that metal lability can be more dependent on the characteristics of the sludge than properties of the soil (Stacey et al., 2001). For example immobilization of soft acids such as silver, by soft bases such as sulphide has been recognized in biosolids (Donner et al., 2015; Donner et al., 2013). This suggests that $\mathrm{Ni}$, as an intermediate metal cation, will be more strongly held by carboxyl groups in the organic matter of the sludge and remain labile. In contrast to $\mathrm{Ni}$, total $\mathrm{Zn}$ concentrations in the Urban soils (mean $=283 \mathrm{mg} \mathrm{kg}^{-1} ; \mathrm{SD}=178 \mathrm{mg} \mathrm{kg}^{-1}$ ) were generally higher than in most soils in England and Wales in which $\mathrm{Zn}$ is typically $<100 \mathrm{mg} \mathrm{kg}^{-1}$ unless contaminated by minespoil (Rawlins et al., 2012). 
It is difficult to summarize the effect of land use on metal lability for the whole dataset because of the complex range of Zn sources. For example, from field notes, metals in soil WV20 were probably associated with canal dredgings whereas soil WV25 was contaminated from its location in an industrial estate and proximity to a railway - but both soils had similar values of $\% \mathrm{Zn}_{\mathrm{E}}(27.7 \%$ and $20.6 \%$ respectively). There was only one sample where $\mathrm{Zn}$ lability was, unexpectedly, underestimated by the MA-parameterized model and fell slightly outside of the RSD range: soil WV3 was a slightly acidic woodland soil $(\mathrm{pH}=6.1)$ with very high DOC concentrations $\left(180 \mathrm{mg} \mathrm{L}^{-1}\right.$ in $\left.0.01 \mathrm{M} \mathrm{CaCl}_{2}, 1 \mathrm{~g}: 30 \mathrm{~mL}\right)$.

\subsection{Aging of Cd and Zn in air dried soils during storage}

The difference between values of $\mathrm{M}_{\mathrm{E}}$ measured in the current study and $\mathrm{M}_{\mathrm{E}}$ * measured by Tye et al. (2003) for $\mathrm{Cd}$ and $\mathrm{Zn}$ may be a consequence of processes occurring within the soils or it may be the result of analytical artefacts in either of the two methods (Fig. 4). Only a limited number of studies have compared the measurement of metal lability using both radio-isotopes and stable isotopes. Sterckeman et al. (2009) compared Cd lability measured using ${ }^{111} \mathrm{Cd}$ (stable; $\mathrm{M}_{\mathrm{E}}$ ) and ${ }^{109} \mathrm{Cd}$ (radioactive; $\mathrm{M}_{\mathrm{E}}{ }^{*}$ ) and found that the results were equivalent but that $\mathrm{M}_{\mathrm{E}}$ data were more repeatable. Considering the range of properties of the MA soils, continuing fixation of Zn may have occurred in some soils. Even in air-dried soils, particles may have thin films of surface hydration which could mean that the soil remains sufficiently chemically reactive to allow solid phase matrix- and surface-diffusion processes.

The greater difference between $\mathrm{M}_{\mathrm{E}}$ and $\mathrm{M}_{\mathrm{E}}{ }^{*}$ for the Urban soils was surprising as there was no expectation of measureable metal fixation during the 12 years of air dry storage prior to measurement of $\mathrm{M}_{\mathrm{E}}$ in August and September 2011 whereas further slow fixation in the MA soils was expected. This result may indicate a methodological difference. Values of $\mathrm{M}_{\mathrm{E}}{ }^{*}$ were determined using flame-AAS and graphite furnace-AAS measurement of $\mathrm{Cd}$ and $\mathrm{Zn}$ combined with radio-assay of ${ }^{109} \mathrm{Cd}$ and ${ }^{65} \mathrm{Zn}$ in solution following centrifugation of soil suspensions at $2200 \mathrm{~g}$. Values of $\mathrm{M}_{\mathrm{E}}$ were determined solely by ICP-MS following additional filtration to $<0.22 \mu \mathrm{m}$. Thus, the (large) values of $\mathrm{M}_{\mathrm{E}}{ }^{*}$ measured in 1999 may have been more susceptible to the influence of non-labile metal in suspended submicron particles (Lombi et al., 2003) - an effect which is enhanced at (i) higher $\mathrm{pH}$ values, (ii) lower soluble metal concentrations and (iii) lower values of $\% \mathrm{M}_{\mathrm{E}}$ - which are all characteristics of the Urban soils.

\subsection{Effect of non-labile soil colloidal particles on measured E-value}

504 A strong correlation between $\% \mathrm{M}_{\mathrm{E}}$ and $\% \mathrm{M}_{\mathrm{Er}}$ was expected because as metal lability increases there is 505 less scope for a substantial effect from non-labile SCP-metal as $\mathrm{M}_{\mathrm{Er}}$ gradually approaches the value of $506 \mathrm{M}_{\mathrm{E}}$ at $100 \%$ lability. The increase in $\mathrm{Cu}_{\mathrm{E}} / \mathrm{Cu}_{\mathrm{Er}}$ with $\mathrm{pH}$ (Fig. 2b) is in agreement with previous explanations of more mobile geocolloidal particles in the soil solution at higher $\mathrm{pH}$ values (Lombi et al., 2003; Nolan et al., 2009; Marzouk et al., 2013b). The presence of non-labile soluble $\mathrm{Cu}$ has also been shown to arise from strong adsorption of $\mathrm{Cu}$ on humic acid (Mao et al., 2015) whereas other trace metal ions $(\mathrm{Cd}, \mathrm{Ni}, \mathrm{Pb}$ and $\mathrm{Zn})$ are more likely to be associated with colloidal $\mathrm{Fe}, \mathrm{Al}$ and $\mathrm{Mn}$ oxides (Lombi et al., 2003; Ma et al., 2006a; Nolan et al., 2009). However, in this work no significant 
correlation ( $p>0.05$ ) was observed between the ratio of $\mathrm{M}_{\mathrm{E}}: \mathrm{M}_{\mathrm{Er}}$ and solution concentration of $\mathrm{Fe}, \mathrm{Al}$, $\mathrm{Mn}$ or DOC measured in $0.01 \mathrm{M} \mathrm{Ca}\left(\mathrm{NO}_{3}\right)_{2}$ (solid: solution ratio $1 \mathrm{~g}: 30 \mathrm{~mL}$ ).

\subsection{Prediction of metal solubility and fractionation with WHAM-VII}

Metal binding

516 For all five metals the relative importance of Fe-oxides for metal binding appeared to increase with increasing $\mathrm{pH}$ whilst that of organic matter (HA and FA) decreased (Fig. 6). The pH-dependency of metal adsorption to Fe oxide is stronger than that of organic matter (Weng et al., 2004) and Fe oxide appeared to control metal binding at high $\mathrm{pH}(>\mathrm{pH} 7)$, except in the case of $\mathrm{Cu}$ where organic matter was most important. Most of the $\mathrm{Cu}(>91.0 \%)$ and $\mathrm{Pb}(>92.3 \%)$ were absorbed by the soil across the $\mathrm{pH}$ range, even at low $\mathrm{pH}$ values, although there were substantial differences in their affinity for particular binding phases.

Errors associated with modelling

Errors in prediction of metal solubility may arise for reasons originating in both modelling and measurement. Model shortcomings may include poor parameterisation of the 'pure' geocolloidal metal binding parameters and failure to include all binding phases. The default constants in WHAM were originally parameterized on single geocolloidal systems and the most comprehensive datasets used in the sub-model employed (Model VII) were from studies of metal binding by purified humic and fulvic acids. Therefore it is likely that soils in which humus is the dominant adsorption surface are likely to perform better than those with complex assemblages of organic and mineral geocolloids. As suggested by Smith et al. (2004) the properties of the cation binding sites of humic substances in peat appear very similar to those of isolated humic substances. It has also been shown in other studies that prediction of the trace metal solubility with multi-surface geochemical models is more successful when solid $\rightleftharpoons$ solution partitioning is controlled mainly by soil organic matter (Weng et al., 2002; Cances et al., 2003). on mineral oxides may be less rigorous in (i) combining all soil oxide adsorbents into just three types (Al, Mn and Fe oxides) and (ii) using a single parameter to describe heterogeneity for all metals (Lofts and Tipping, 1998) and oxides (default setting). Such simplifications are reasonable to avoid the need for a large parameter database limiting the applicability of the model. However, it may also be the reason for greater deviation from measured values in predicting solubility in high $\mathrm{pH}$ soils in which oxides are the dominant metal binding phases. Soils will have a range of oxide minerals, which vary in surface charge characteristics, surface morphology/area, crystallinity and degree of surface contamination with adsorbed anions and humus acids. All of these factors together will generate a range of adsorption strengths for metal cations. As $\mathrm{pH}$ rises, a greater range of metal oxides contribute to cation binding and so the diversity of oxide surfaces involved in metal adsorption will increase. Therefore, if a speciation model generates error in predicting metal binding on oxides surfaces, the effect is likely to be more significant in high $\mathrm{pH}$ soils as there is an accumulation of error contributed 
by each oxide phase. In addition, there are other binding phases in soils which may actively adsorb metal cations especially in high $\mathrm{pH}$ soils. For example, calcite $\left(\mathrm{CaCO}_{3}\right)$ and hydroxyapatite $\left(\mathrm{Ca}_{5}\left(\mathrm{PO}_{4}\right)_{3}(\mathrm{OH})\right)$, which are only likely to be present in soils with high $\mathrm{pH}(>7.0$ and $>6.0$ respectively), can adsorb metal cations by surface replacement of $\mathrm{Ca}^{2+}$ on mineral surface sites (Davis et al., 1987; Ahmed et al., 2008; Bailey et al., 2005). The exclusion of these phases in the WHAM model may contribute to the general over-prediction of solution metal concentration at high $\mathrm{pH}$. Alternative explanations offered within the literature include a failure to account for (i) synergistic effects associated with adsorption on mixed oxide-humic surfaces (Heidmann et al., 2005; Pedrot, et al., 2009); (ii) the existence of highly specific sites on Fe oxides with much greater intrinsic stability constants than used in the general surface complexation model (Buekers et al., 2008b; Linde et al., 2007) or (iii) formation of discrete solid phases such as chloropyromorphite $\left(\mathrm{Pb}_{5}\left(\mathrm{PO}_{4}\right)_{3} \mathrm{Cl}\right)$ (Degryse et al., 2009), which is likely to affect $\mathrm{Pb}$ dynamics in some of the Urban and sewage sludged soils.

Errors associated with measurement

Reasons for over-estimation and scatter in predicted solubility may lie not only with model limitations but also with the measurements undertaken to provide model inputs. Using reactive trace metal concentrations based on $\mathrm{M}_{\mathrm{E}}$ values instead of 'total' improves the model prediction (Marzouk et al., 2013b). However, poor model input data is also likely to arise from the various 'proxies' that are used to represent geocolloidal binding phases. For example soil organic carbon is typically used to estimate soil humic and fulvic acid while the $\mathrm{Fe}, \mathrm{Al}$ and $\mathrm{Mn}$ oxide phases are rather crudely represented by elemental extraction with a reducing reagent such as dithionite-citrate-bicarbonate solution. A significant underestimation of measured solubility (> RSD) was seen for a small number of soils (e.g. WV7 for $\mathrm{Ni}, \mathrm{Cu}$ and $\mathrm{Pb}$; WV10 for Pb, Figure 5). This may be a result of overestimation of some of the binding phases. For example, for soil WV7, WHAM predicted $70 \%, 83 \%$ and $97 \%$ of binding on $\mathrm{Fe}$ oxides for $\mathrm{Cu}, \mathrm{Ni}$ and $\mathrm{Pb}$, and the bias was-1.62, -0.83 , and -2.25 respectively; this implies over prediction of metal binding on $\mathrm{Fe}$ oxides. Given that generally the model algorithms underestimate metal binding on mineral oxides, overestimation of metal binding suggests that, for these soils, the DCB method extracted more Fe than was actually present in the Fe oxides phase, leading to an overestimation of the Fe oxide content.

Bias in prediction of metal solubility in Urban soils

WHAM prediction of solubility in Urban soils generally produced a poorer correlation than that for MA soils. This may be the result of slightly higher $\mathrm{pH}$ values in Urban soils as a consequence of the presence of alkaline wastes such as cement, concrete etc. (Bridges, 1991; Rosenbaum et al., 2003). The higher metal sorption capacity seen in some brownfield soils, compared to non-urban soils, is thought to involve processes of both sorption and precipitation (Markiewiez-Patkowska et al., 2005; Mclean and Bledsoe, 1992). Some particular examples include (i) a large bias $(\Delta \mathrm{pM})$ observed for $\mathrm{Zn}$ and $\mathrm{Pb}$ with values of 1.7 and 1.8 respectively in soil WV21; (ii) extremely low metal solution concentrations which lead to greater experimental error in some urban soils - e.g. Zn in NG13 with pH 7.0 and total $\mathrm{Zn}$ 
concentration $26 \mathrm{mg} \mathrm{kg}^{-1}$; (iii) a very high binding capacity in sewage farm soils, possibly due to extremely high phosphate concentrations from the sewage sludge resulting in overestimation of $\mathrm{Cd}$ solution concentrations in NG14 and NG15.

\section{CONCLUSIONS}

For all five metals, lability in the MA soils was significantly greater than in the Urban soils, although the relative lability of the five metals followed the same sequence $(\mathrm{Cd}>\mathrm{Pb} \geq \mathrm{Cu}>\mathrm{Zn}>\mathrm{Ni})$ in both sets of soils. Lower metal lability in the Urban soils may reflect longer soil-metal contact times but also strongly suggests that metal source characteristics are more important. In the MA soils, a good prediction of \%E-value was achieved using both linear and logistic models with $\mathrm{pH}$ value as clearly the most important soil property. Lability of $\mathrm{Cu}$ was least affected by soil properties. The addition of $\mathrm{FeOx}$ improved the prediction for $\mathrm{Ni}$ and $\mathrm{Zn}$ lability, while $\mathrm{MnOx}$ was important for $\mathrm{Pb}$ at $\mathrm{pH}$ values $<5.5$. However, although the performance of the logistic model was no better than the linear one, it offers more realistic boundaries to model outcomes $\left(\% \mathrm{M}_{\mathrm{E}}=0-100 \%\right)$ and is therefore perhaps a more robust model for predicting metal lability solely from soil properties and more useful than regression coefficients for comparative purposes. Soil $\mathrm{pH}$ affected metal lability in the Urban soils in a trend qualitatively similar to that of the MA soils. However, in all cases, the effect of contaminant source was evident from gross over-prediction of \%E-value in Urban soils using logistic models parameterized with data from the MA soils. Continuing fixation of $\mathrm{Cd}$ and $\mathrm{Zn}$ may have occurred during soil storage. A more pronounced difference between $\mathrm{M}_{\mathrm{E}}$ and $\mathrm{M}_{\mathrm{E}}$ * was observed in high $\mathrm{pH}$ soils than in acidic soils. However, the difference between lability measured in 1999 and in the current study may also be due to the influence of non-labile SCP-metal in the earlier measurement.

Overall WHAM-VII predicted trace metal solubility reasonably well for both sets of soils and bias was observed mainly in soils with low metal solubility and relatively high soil $\mathrm{pH}$ values. For $\mathrm{Cd}, \mathrm{Ni}$ and $\mathrm{Zn}$, the bias observed was primarily associated with the proportion of labile metal predicted to bind to $\mathrm{Fe}$ oxides. In the case of $\mathrm{Cu}$ solubility, prediction bias was affected by $\mathrm{Cu}$ binding to particulate $\mathrm{Mn}$ oxides, and HA and colloidal (dissolved) FA. Of the five metals, Pb solubility was most poorly described. Solubility of all metals was predicted more accurately in the MA soils than in the Urban soils. This was likely to be the result of slightly higher $\mathrm{pH}$ values in the Urban soils or could indicate that the influence of metal source was not completely eliminated by using isotopically exchangeable metal as our best estimate of the labile metal pool required as input to WHAM VII. The poorer performance of WHAM-VII in predicting metal solubility in high $\mathrm{pH}$ soils may be the result of errors in modelling, including the exclusion of potential adsorption surfaces such as $\mathrm{CaCO}_{3}$, or simplicity of the sub-model describing metal binding with mineral oxides. However there must also be considerable error associated with the simplistic representation of binding phases by measurement of 'extractable' Fe and bulk soil organic carbon.

\section{ACKNOWLEDGEMENTS}


621 Published with permission of the director of BGS. We want to thank Ezzat Marzouk for assisting with 622 isotope dilution work and the Collins' calcimeter method. Lingchen Mao acknowledges financial 623 support from the University of Nottingham. We acknowledge the use of some data originally produced 624 through funding from BBSRC grant award TO6499 and the NERC Urban Regeneration of the 625 Environment programme (grant No. GST/03/2251). 
627

628

629

630

631

632

633

634

635

636

637

638

639

640

641

642

643

644

645

646

647

648

649

650

651

652

653

654

655

656

657

658

659

660

661

662

663

Ahmed, I.A.M., Crout, N.M.J., Young, S.D., 2008. Kinetics of Cd sorption, desorption and fixation by calcite: A long-term radiotracer study. Geochim. Cosmochim. Acta 72, 1498-1512.

Almas, A.R., Lofts, S., Mulder, J., Tipping, E., 2007. Solubility of major cations and $\mathrm{Cu}, \mathrm{Zn}$ and $\mathrm{Cd}$ in soil extracts of some contaminated agricultural soils near a zinc smelter in Norway: modelling with a multisurface extension of WHAM. European journal of soil science 58, 13.

Anschutz, P., Zhong, S.J., Sundby, B., Mucci, A., Gobeil, C., 1998. Burial efficiency of phosphorus and the geochemistry of iron in continental margin sediments. Limnology and Oceanography 43, 5364.

Atkinson, N.R., Bailey, E.H., Tye, A.M., Breward, N., Young, S.D., 2011. Fractionation of lead in soil by isotopic dilution and sequential extraction. Environmental Chemistry 8, 493-500.

Bailey, E.H., Mosselmans, J.F.W., Young, S.D., 2005. Time-dependent surface reactivity of Cd sorbed on calcite, hydroxylapatite and humic acid. Mineralogical Magazine 69, 563-575.

Basta, N.T., Tabatabai, M.A., 1992. Effect of cropping systmes on adsorption of metals by soils. II. Effect of pH. Soil Science 153, 195-204.

Bonten, L.T.C., Groenenberg, J.E., Weng, L., van Riemsdijk, W.H., 2008. Use of speciation and complexation models to estimate heavy metal sorption in soils. Geoderma 146, 303-310.

Borch, T., Kretzschmar, R., Kappler, A., Van Cappellen, P., Ginder-Vogel, M., Voegelin, A., Campbell, K., 2010. Biogeochemical Redox Processes and their Impact on Contaminant Dynamics. Environ. Sci. Technol. 44, 15-23.

Bridges, E.M., 1991. Waste materials in urban soils, in: Bullock, P., Gregory, P.J., British Society of Soil Science., Nature Conservancy Council. (Eds.), Soils in the urban environment. Blackwell Scientific, Oxford, pp. ix, 174 p.

Buekers, J., Amery, F., Maes, A., Smolders, E., 2008a. Long-term reactions of Ni, Zn and Cd with iron oxyhydroxides depend on crystallinity and structure and on metal concentrations. European Journal of Soil Science 59, 706-715.

Buekers, J., Degryse, F., Maes, A., Smolders, E., 2008b. Modelling the effects of ageing on Cd, Zn, Ni and $\mathrm{Cu}$ solubility in soils using an assemblage model. European Journal of Soil Science 59, 1160-1170.

Buekers, J., Van Laer, L., Amery, F., Van Buggenhout, S., Maes, A., Smolders, E., 2007. Role of soil constituents in fixation of soluble $\mathrm{Zn}, \mathrm{Cu}, \mathrm{Ni}$ and $\mathrm{Cd}$ added to soils. European Journal of Soil Science $58,1514-1524$.

Cances, B., Ponthieu, M., Castrec-Rouelle, M., Aubry, E., Benedetti, M.F., 2003. Metal ions speciation in a soil and its solution: experimental data and model results. Geoderma 113, 341-355.

Charlatchka, R., Cambier, P., 2000. Influence of reducing conditions on solubility of trace metals in contaminated soils. Water Air and Soil Pollution 118, 143-167.

Cheng, H., Li, M., Zhao, C., Li, K., Peng, M., Qin, A., Cheng, X., 2014. Overview of trace metals in the urban soil of 31 metropolises in China. J. Geochem. Explor. 139, 31-52. 
Cheng, T., De Schamphelaere, K., Lofts, S., Janssen, C., Allen, H.E., 2005. Measurement and computation of zinc binding to natural dissolved organic matter in European surface waters. Analytica Chimica Acta 542, 230-239.

Collins, R.N., Merrington, G., McLaughlin, M.J., Morel, J.L., 2003. Organic ligand and pH effects on isotopically exchangeable cadmium in polluted soils. Soil Science Society of America Journal 67, 112121.

Davis, J.A., Fuller, C.C., Cook, A.D., 1987. A model for trace-metal sorption processes at the calcite surface - adsorption of $\mathrm{Cd}^{2+}$ and subsequent solid-solution formation. Geochim. Cosmochim. Acta 51, $1477-1490$.

De Bievre, P., Barnes, I.L., 1985. Table of the isotopic composition of the elements as determined by mass spectrometry. International Journal of Mass Spectrometry and Ion Processes. 65, 211-230.

Degryse, F., Buekers, J., Smolders, E., 2004. Radio-labile cadmium and zinc in soils as affected by pH and source of contamination. European Journal of Soil Science 55, 113-121.

Degryse, F., Smolders, E., Parker, D.R., 2009. Partitioning of metals (Cd, Co, Cu, Ni, Pb, Zn) in soils: concepts, methodologies, prediction and applications - a review. European journal of soil science 60 , 590 .

Degryse, F., Voegelin, A., Jacquat, O., Kretzschmar, R., Smolders, E., 2011. Characterization of zinc in contaminated soils: complementary insights from isotopic exchange, batch extractions and XAFS spectroscopy. European Journal of Soil Science 62, 318-330.

Degryse, F., Waegeneers, N., Smolders, E., 2007. Labile lead in polluted soils measured by stable isotope dilution. European Journal of Soil Science 58, 1-7.

Dermatas, D., Chrysochoou, M., Grubb, D.G., Xu, X.F., 2008. Phosphate treatment of firing range soils: Lead fixation or phosphorus release? Journal of Environmental Quality 37, 47-56.

Dong, D.M., Hua, X.Y., Li, Y., Zhang, J.J., Yan, D.X., 2003. Cd adsorption properties of components in different freshwater surface coatings: The important role of ferromanganese oxides. Environ. Sci. Technol. 37, 4106-4112.

Donner, E., Brunetti, G., Zarcinas, B., Harris, P., Tavakkoli, E., Naidu, R., Lombi, E., 2013. Effects of Chemical Amendments on the Lability and Speciation of Metals in Anaerobically Digested Biosolids. Environ. Sci. Technol. 47, 11157-11165.

Donner, E., Scheckel, K., Sekine, R., Popelka-Filcoff, R.S., Bennett, J.W., Brunetti, G., Naidu, R., McGrath, S.P., Lombi, E., 2015. Non-labile silver species in biosolids remain stable throughout 50 years of weathering and ageing. Environmental Pollution 205, 78-86.

Du Laing, G., Rinklebe, J., Vandecasteele, B., Meers, E., Tack, F.M.G., 2009. Trace metal behaviour in estuarine and riverine floodplain soils and sediments: A review. Science of the Total Environment 407, 3972-3985.

Fairbrother, A., Glazebrook, P.W., Van Straalen, N., Tarazona, J.V., 1999. Test Methods for Hazard Determination of Metals and Sparingly Soluble Metal Compounds in Soils: Summary of a SETAC Pellston Workshop. Society of Environmental Toxicology and Chemistry (SETAC), San Lorenzo de El Escorial, Spain.

Gabler, H.E., Bahr, A., Mieke, B., 1999. Determination of the interchangeable heavy-metal fraction in soils by isotope dilution mass spectrometry. Fresenius Journal of Analytical Chemistry 365, 409-414. 
Gabler, H.E., Bahr, A., Heidkamp, A., Utermann, J., 2007. Enriched stable isotopes for determining the isotopically exchangeable element content in soils. European Journal of Soil Science 58, 746-757.

Gambrell, R.P., 1994. Trace and toxic metals in wetlands - A review. Journal of Environmental Quality $23,883-891$.

710 Gustafsson, J.P., Tiberg, C., Edkymish, A., Kleja, D.B., 2011. Modelling lead(II) sorption to ferrihydrite 711 and soil organic matter. Environmental Chemistry 8, 485-492.

Hammer, D., Keller, C., McLaughlin, M.J., Hamon, R.E., 2006. Fixation of metals in soil constituents and potential remobilization by hyperaccumulating and non-hyperaccumulating plants: Results from an isotopic dilution study. Environmental Pollution 143, 407-415.

Hamon, R.E., McLaughlin, M.J., Cozens, G., 2002. Mechanisms of attenuation of metal availability in in situ remediation treatments. Environ. Sci. Technol. 36, 3991-3996.

Heidmann, I., Christl, I., Kretzschmar, R., 2005. Sorption of $\mathrm{Cu}$ and $\mathrm{Pb}$ to kaolinite-fulvic acid colloids: Assessment of sorbent interactions. Geochim. Cosmochim. Acta 69, 1675-1686.

Hough, R.L., Tye, A.M., Crout, N.M.J., McGrath, S.P., Zhang, H., Young, S.D., 2005. Evaluating a

'Free Ion Activity Model' applied to metal uptake by Lolium perenne L. grown in contaminated soils. Plant and Soil 270, 1-12.

Jacquat, O., Voegelin, A., Kretzschmar, R., 2009. Local coordination of Zn in hydroxy-interlayered minerals and implications for Zn retention in soils. Geochim. Cosmochim. Acta 73, 348-363.

Kaste, J.M., Bostick, B.C., Friedland, A.J., Schroth, A.W., Siccama, T.G., 2006. Fate and speciation of gasoline-derived lead in organic horizons of the northeastern USA. Soil Science Society of America Journal 70, 1688-1698.

Komarek, M., Ettler, V., Chrastny, V., Mihaljevic, M., 2008. Lead isotopes in environmental sciences: A review. Environment International 34, 562-577.

Lamy, I., Bourgeois, S., Bermond, A., 1993. Soil Cadmium mobility as a consequence of sewage-sludge disposal. Journal of Environmental Quality 22, 731-737.

Lang, F., Kaupenjohann, M., 2003. Effect of dissolved organic matter on the precipitation and mobility of the lead compound chloropyromorphite in solution. European Journal of Soil Science 54, 139-147.

Linde, M., Oborn, I., Gustafsson, J.P., 2007. Effects of changed soil conditions on the mobility of trace metals in moderately contaminated urban soils. Water Air and Soil Pollution 183, 69-83.

Lock, K., Janssen, C.R., 2001. Ecotoxicity of zinc in spiked artificial soils versus contaminated field soils. Environ. Sci. Technol. 35, 4295-4300.

Lofts, S., Tipping, E., 1998. An assemblage model for cation binding by natural particulate matter. Geochim. Cosmochim. Acta 62, 2609-2625.

Lombi, E., Hamon, R.E., McGrath, S.P., McLaughlin, M.J., 2003. Lability of Cd, Cu, and $\mathrm{Zn}$ in polluted soils treated with lime, beringite, and red mud and identification of a non-labile colloidal fraction of metals using isotopic techniques. Environ. Sci. Technol. 37, 979-984.

Ma, Y.B., Lombi, E., Nolan, A.L., McLaughlin, M.J., 2006a. Determination of labile $\mathrm{Cu}$ in soils and isotopic exchangeability of colloidal Cu complexes. European Journal of Soil Science 57, 147-153.

Ma, Y.B., Lombi, E., Nolan, A.L., McLaughlin, M.J., 2006b. Short-term natural attenuation of copper in soils: Effects of time, temperature, and soil characteristics. Environmental Toxicology and Chemistry $25,652-658$. 
MAFF, 1993. Code of good agricultural practice for the protection of soil. Ministry of Agriculture Fisheries and Food, Welsh Office Agriculture Department, London.

749

750

751

752

Malinovsky, D., Dahlqvist, R., Baxter, D.C., Ingri, J., Rodushkin, I., 2005. Performance of diffusive gradients in thin films for measurement of the isotopic composition of soluble $\mathrm{Zn}$. Analytica Chimica Acta 537, 401-405.

Manceau, A., Schlegel, M.L., Musso, M., Sole, V.A., Gauthier, C., Petit, P.E., Trolard, F., 2000. Crystal chemistry of trace elements in natural and synthetic goethite. Geochim. Cosmochim. Acta 64, 36433661 .

Manta, D.S., Angelone, M., Bellanca, A., Neri, R., Sprovieri, M., 2002. Heavy metals in urban soils: a case study from the city of Palermo (Sicily), Italy. Science of the Total Environment 300, 229-243.

Mao, L.C., Young, S.D., Bailey, E.H., 2015. Lability of copper bound to humic acid. Chemosphere 131, 201-208.

Mao, L.C., Bailey, E.H., Chester, J., Dean, J., Ander, E.L., Chenery, S.R., Young, S.D., 2014. Lability of $\mathrm{Pb}$ in soil: effects of soil properties and contaminant source. Environmental Chemistry 11, 690-701.

Markiewiez-Patkowska, J., Hursthouse, A., Przybyla-Kij, H., 2005. The interaction of heavy metals with urban soils: sorption behaviour of $\mathrm{Cd}, \mathrm{Cu}, \mathrm{Cr}, \mathrm{Pb}$ and $\mathrm{Zn}$ with a typical mixed brownfield deposit. Environment International 31, 513-521.

Marzouk, E.R., Chenery, S.R., Young, S.D., 2013a. Measuring reactive metal in soil: a comparison of multi-element isotopic dilution and chemical extraction. European Journal of Soil Science 64, 526-536.

Marzouk, E.R., Chenery, S.R., Young, S.D., 2013b. Predicting the solubility and lability of Zn, Cd, and $\mathrm{Pb}$ in soils from a minespoil-contaminated catchment by stable isotopic exchange. Geochim. Cosmochim. Acta 123, 1-16.

McBride, M.B., Barrett, K.A., Kim, B., Hale, B., 2006. Cadmium sorption in soils 25 years after amendment with sewage sludge. Soil Science 171, 21-28.

McLean, J.E., Bledsoe, B.E., 1992. Behavior of metals in soils, Ground Water Issue.

Midwood, A.J., 2007. Stable isotope methods for estimating the labile metal content of soils, in: Willey, N. (Ed.), Phytoremediation : methods and reviews. Humana Press, Totowa, N.J.

Nakhone, L.N., Young, S.D., 1993. The significance of (radio-)labile cadmium pools in soil. Environmental Pollution 82, 73-77.

Nazif, W., Marzouk, E.R., Perveen, S., Crout, N.M.J., Young, S.D., 2015. Zinc solubility and fractionation in cultivated calcareous soils irrigated with wastewater. Science of the Total Environment $518,310-319$.

Nolan, A.L., Ma, Y.B., Lombi, E., McLaughlin, M.J., 2009. Speciation and Isotopic Exchangeability of Nickel in Soil Solution. Journal of Environmental Quality 38, 485-492.

Pedrot, M., Dia, A., Davranche, M., 2009. Double pH control on humic substance-borne trace elements distribution in soil waters as inferred from ultrafiltration. Journal of Colloid and Interface Science 339, 390-403.

Piper, C.S., 1954. Soil and plant analysis : a laboratory manual of methods for the examination of soils and the determination of the inorganic constituents of plants. International Science Publisher Inc., New York. 
Rawlins, B.G., McGrath, S.P., Scheib, A.J., Breward, N., Cave, M., Lister, T.R., Ingham, M., Gowing, C., Carter, S., 2012. The advanced soil geochemical atlas of England and Wales. British Geological Survey, Nottingham, UK, p. 227.

Rieuwerts, J.S., Ashmore, M.R., Farago, M.E., Thornton, I., 2006. The influence of soil characteristics on the extractability of $\mathrm{Cd}, \mathrm{Pb}$ and $\mathrm{Zn}$ in upland and moorland soils. Science of the Total Environment $366,864-875$.

Rodrigues, S.M., Henriques, B., da Silva, E.F., Pereira, M.E., Duarte, A.C., Groenenberg, J.E., Romkens, P., 2010. Evaluation of an approach for the characterization of reactive and available pools of 20 potentially toxic elements in soils: Part II - Solid-solution partition relationships and ion activity in soil solutions. Chemosphere 81, 1560-1570.

Rosenbaum, M.S., McMillan, A.A., Powell, J.H., Cooper, A.H., Culshaw, M.G., Northmore, K.J., 2003. Classification of artificial (man-made) ground. Engineering Geology 69, 399-409.

Shi, Z.Q., Di Toro, D.M., Allen, H.E., Sparks, D.L., 2008. A WHAM-based kinetics model for Zn adsorption and desorption to soils. Environ. Sci. Technol. 42, 5630-5636.

Sinitsyn, V.A., Aja, S.U., Kulik, D.A., Wood, S.A., 2000. Acid-base surface chemistry and sorption of some lanthanides on $\mathrm{K}+$-saturated marblehead illite: I. Results of an experimental investigation. Geochim. Cosmochim. Acta 64, 185-194.

Smith, E.J., Rey-Castro, C., Longworth, H., Lofts, S., Lawlor, A.J., Tipping, E., 2004. Cation binding by acid-washed peat, interpreted with humic ion-binding model VI-FD. European Journal of Soil Science 55, 433-447.

Smolders, E., Brans, K., Foldi, A., Merckx, R., 1999. Cadmium fixation in soils measured by isotopic dilution. Soil Science Society of America Journal 63, 78-85.

Stacey, S., Merrington, G., McLaughlin, M.J., 2001. The effect of aging biosolids on the availability of cadmium and zinc in soil. European Journal of Soil Science 52, 313-321.

Stenberg, A., Andren, H., Malinovsky, D., Engstrom, E., Rodushkin, I., Baxter, D.C., 2004. Isotopic variations of $\mathrm{Zn}$ in biological materials. Analytical Chemistry 76, 3971-3978.

Sterckeman, T., Carignan, J., Srayeddin, I., Baize, D., Cloquet, C., 2009. Availability of soil cadmium using stable and radioactive isotope dilution. Geoderma 153, 372-378.

Tack, F.M.G., 2010. Trace Elements: General Soil Chemistry, Principles and Processes, in: Hooda, P.S. (Ed.), Trace elements in soils. Wiley, Chichester, pp. 9-39.

Thornton, I., Farago, M.E., Thums, C.R., Parrish, R.R., McGill, R.A.R., Breward, N., Fortey, N.J., Simpson, P., Young, S.D., Tye, A.M., Crout, N.M.J., Hough, R.L., Watt, J., 2008. Urban geochemistry: research strategies to assist risk assessment and remediation of brownfield sites in urban areas. Environmental Geochemistry and Health 30, 565-576.

Tipping, E., Rieuwerts, J., Pan, G., Ashmore, M.R., Lofts, S., Hill, M.T.R., Farago, M.E., Thornton, I., 2003. The solid-solution partitioning of heavy metals $(\mathrm{Cu}, \mathrm{Zn}, \mathrm{Cd}, \mathrm{Pb})$ in upland soils of England and Wales. Environmental Pollution 125, 213-225.

Trivedi, P., Axe, L., 2001. Predicting divalent metal sorption to hydrous Al, Fe, and Mn oxides. Environ. Sci. Technol. 35, 1779-1784.

Tye, A.M., Young, S., Crout, N.M.J., Zhang, H., Preston, S., Zhao, F.J., McGrath, S.P., 2004. Speciation and solubility of $\mathrm{Cu}, \mathrm{Ni}$ and $\mathrm{Pb}$ in contaminated soils. European Journal of Soil Science 55, 579-590. 
831 McGrath, S.P., Paton, G.I., Kilham, K., Resende, L., 2003. Predicting the activity of $\mathrm{Cd}^{2+}$ and $\mathrm{Zn}^{2+}$ in

832 soil pore water from the radio-labile metal fraction. Geochim. Cosmochim. Acta 67, 375-385.

833 Wei, B., Yang, L., 2010. A review of heavy metal contaminations in urban soils, urban road dusts and agricultural soils from China. Microchemical Journal 94, 99-107.

835 Weng, L.P., Temminghoff, E.J.M., Lofts, S., Tipping, E., Van Riemsdijk, W.H., 2002. Complexation 836 with dissolved organic matter and solubility control of heavy metals in a sandy soil. Environ. Sci. 837 Technol. 36, 4804-4810.

838 Weng, L.P., Temminghoff, E.J.M., van Riemsdijk, W.H., 2001. Contribution of individual sorhents to 839 the control of heavy metal activity in sandy soil. Environ. Sci. Technol. 35, 4436-4443.

840 Weng, L.P., Wolthoorn, A., Lexmond, T.M., Temminghoff, E.J.M., Van Riemsdijk, W.H., 2004. 841 Understanding the effects of soil characteristics on phytotoxicity and bioavailability of nickel using 842 speciation models. Environ. Sci. Technol. 38, 156-162.

843 Xu, Y., Boonfueng, T., Axe, L., Maeng, S., Tyson, T., 2006. Surface complexation of Pb(II) on 844 amorphous iron oxide and manganese oxide: Spectroscopic and time studies. Journal of Colloid and 845 Interface Science 299, 28-40.

846 Young, S.D., Tye, A., Carstensen, A., Resende, L., Crout, N., 2000. Methods for determining labile 847 cadmium and zinc in soil. European Journal of Soil Science 51, 129-136.

848 Zimdahl, R.L., Skogerboe, R.K., 1977. Behavior of lead in soil. Environ. Sci. Technol. 11, 1202-1207. 


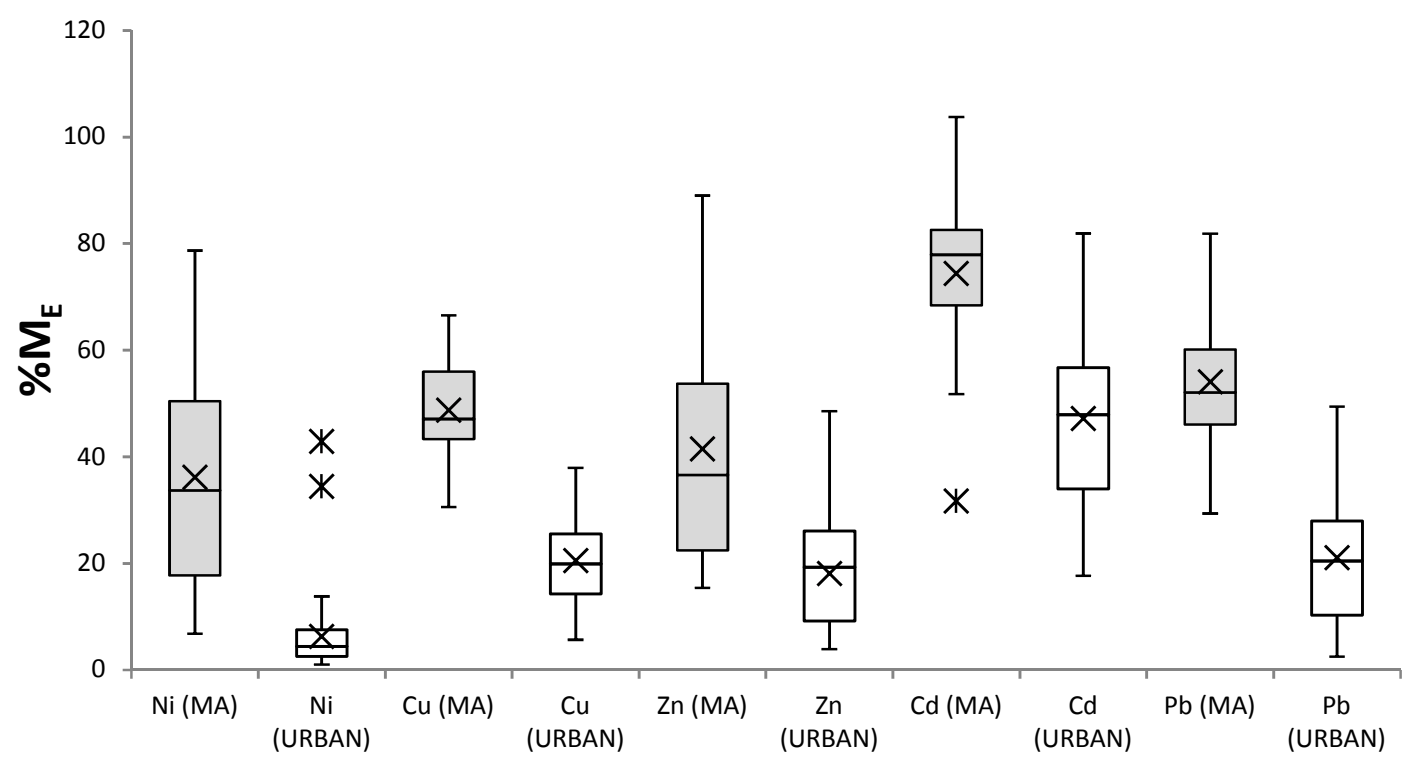

Figure 1: Box and whisker plot showing lability of $\mathrm{Cd}, \mathrm{Cu}, \mathrm{Ni}, \mathrm{Pb}$ and $\mathrm{Zn}\left(\% \mathrm{M}_{\mathrm{E}}\right)$ for $\mathrm{MA}$ soils (23) and Urban soils (50); the mean value $(x)$ is also shown and outliers are marked as an asterisk. 

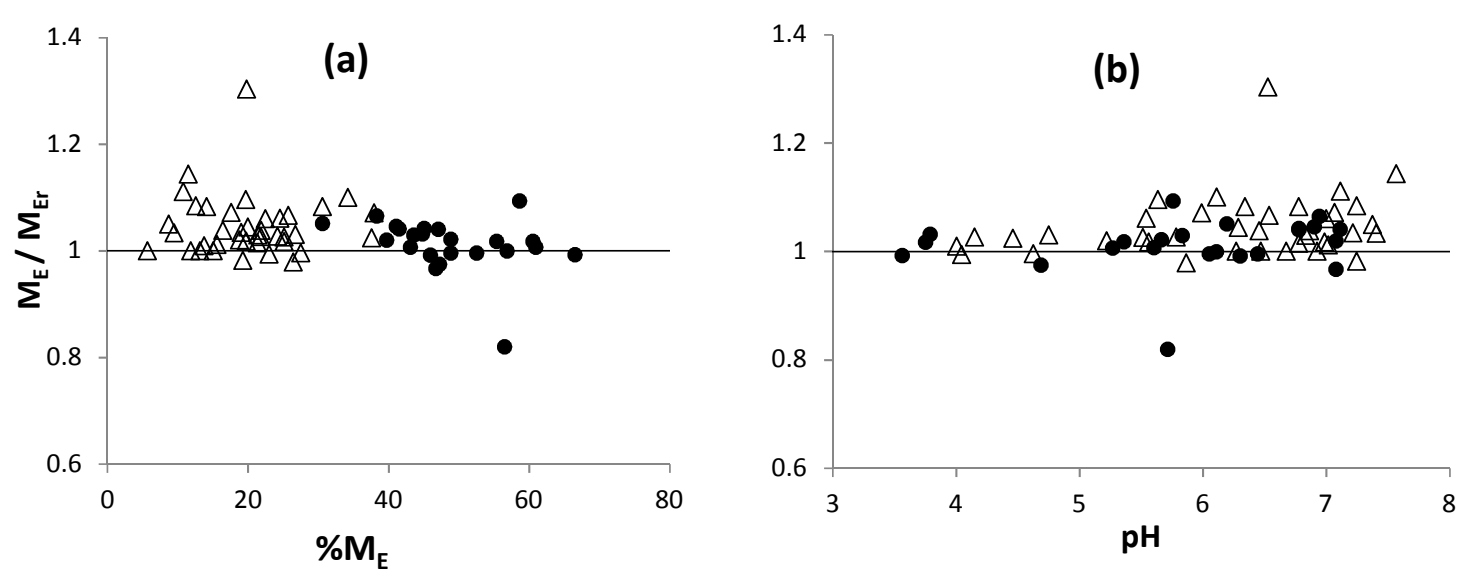

Figure 2: Ratio of $\mathrm{M}_{\mathrm{E}}$ : $\mathrm{M}_{\mathrm{Er}}$ as a function of $\% \mathrm{M}_{\mathrm{E}}(\mathrm{a})$ and $\mathrm{pH}(\mathrm{b})$ for $\mathrm{Cu}$ in $\mathrm{MA}(\bullet)$ and Urban $(\Delta)$ soils. 

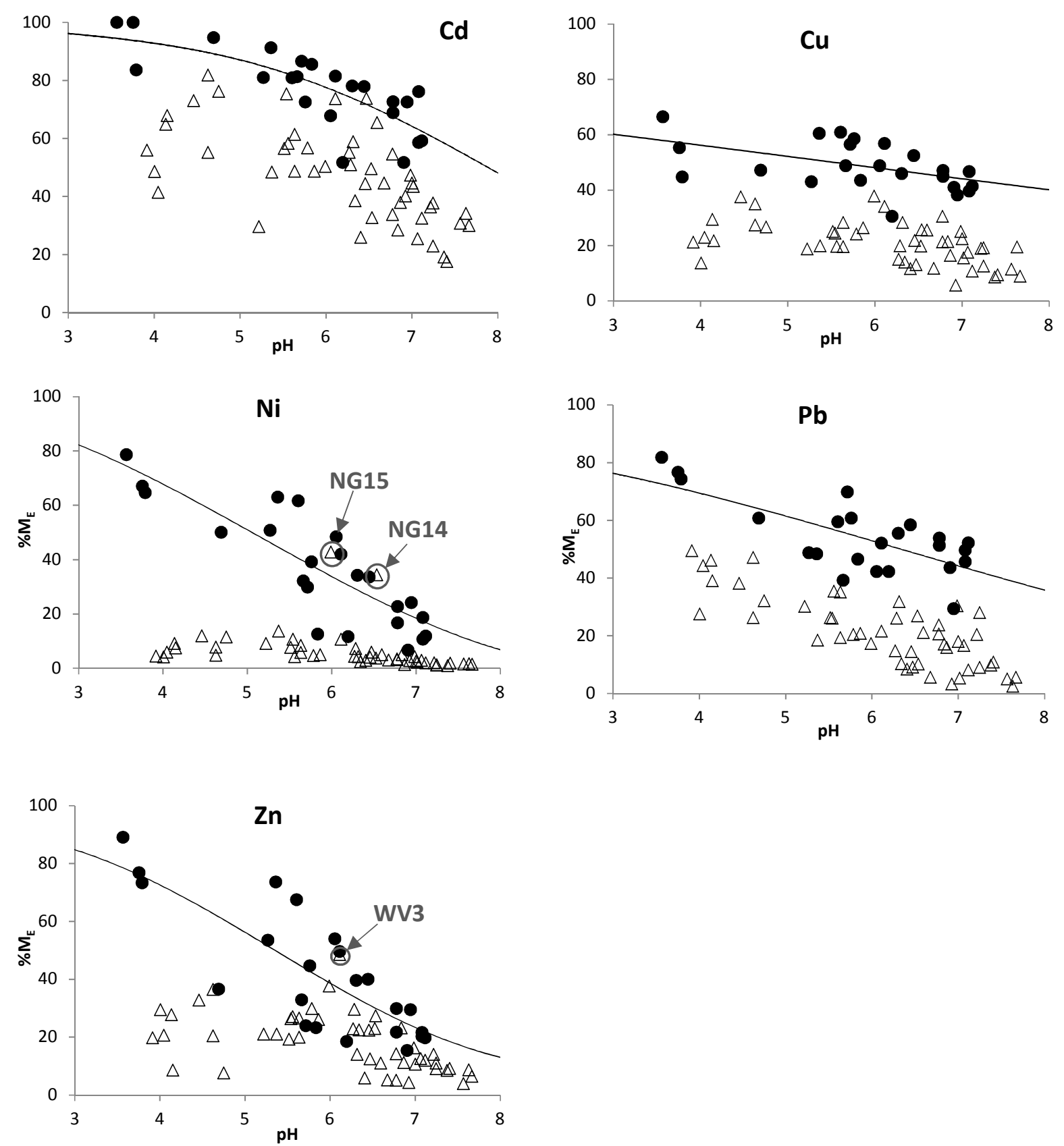

Figure 3: Measured values of $\% \mathrm{M}_{\mathrm{E}}(\mathrm{Cd}, \mathrm{Cu}, \mathrm{Ni}, \mathrm{Pb}$ and $\mathrm{Zn})$ for $\mathrm{MA}(\bullet)$ and $\mathrm{Urban}(\Delta)$ soils. The solid line represents the predicted trend in $\% \mathrm{M}_{\mathrm{E}}$ from Equation 4. 

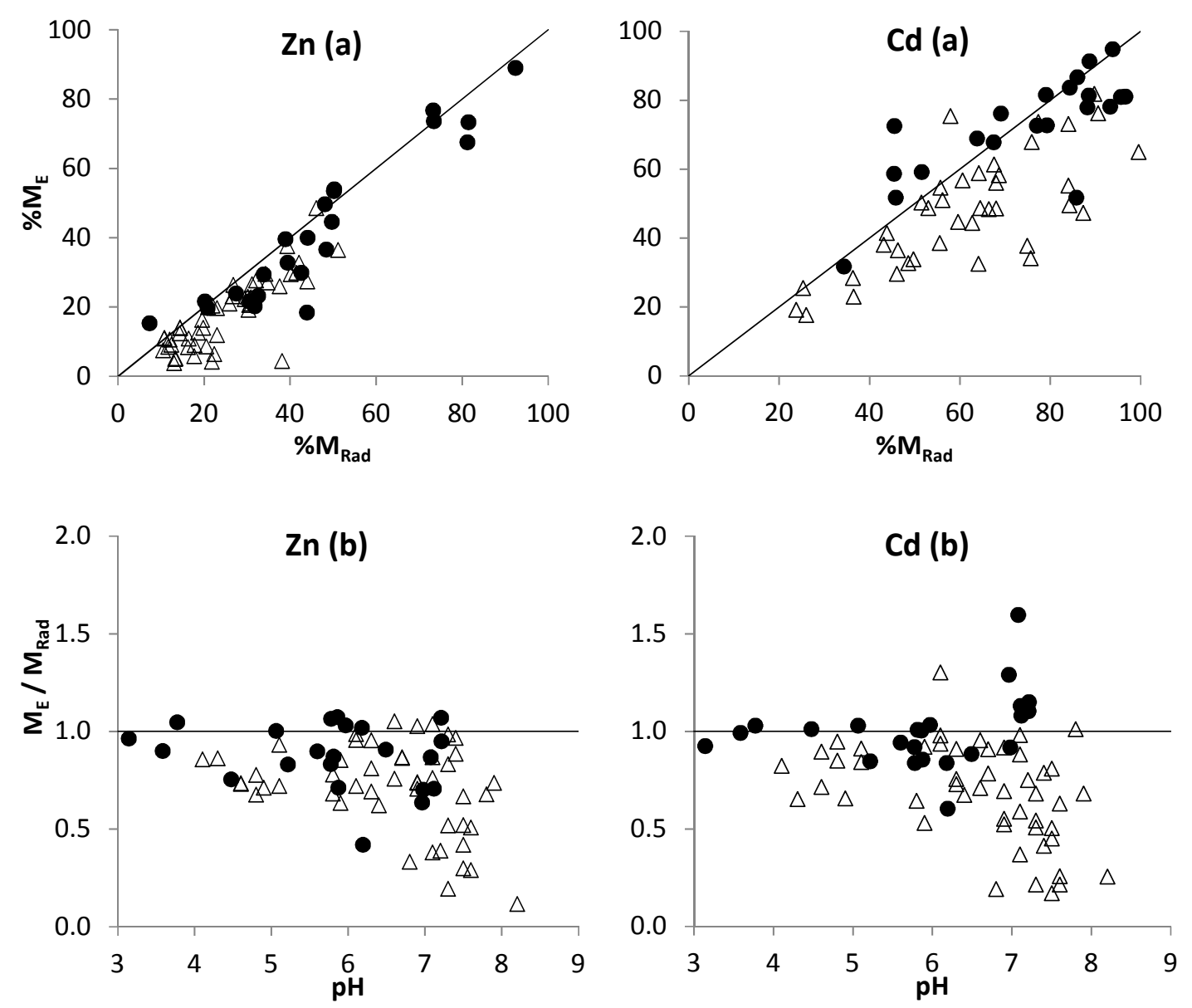

Figure 4: (a) Comparison of $\% \mathrm{M}_{\mathrm{E}}$ (this study) and $\% \mathrm{M}_{\mathrm{E}}{ }^{*}$ (Tye et al., 2003) for $\mathrm{Zn}$ and $\mathrm{Cd}$ in $\mathrm{MA}(\bullet)$ and Urban ( $\Delta$ ) soils; the solid line is the 1: 1 line. (b) The ratio of $\mathrm{M}_{\mathrm{E}}: \mathrm{M}_{\mathrm{Rad}}$ as a function of $\mathrm{pH}$. 

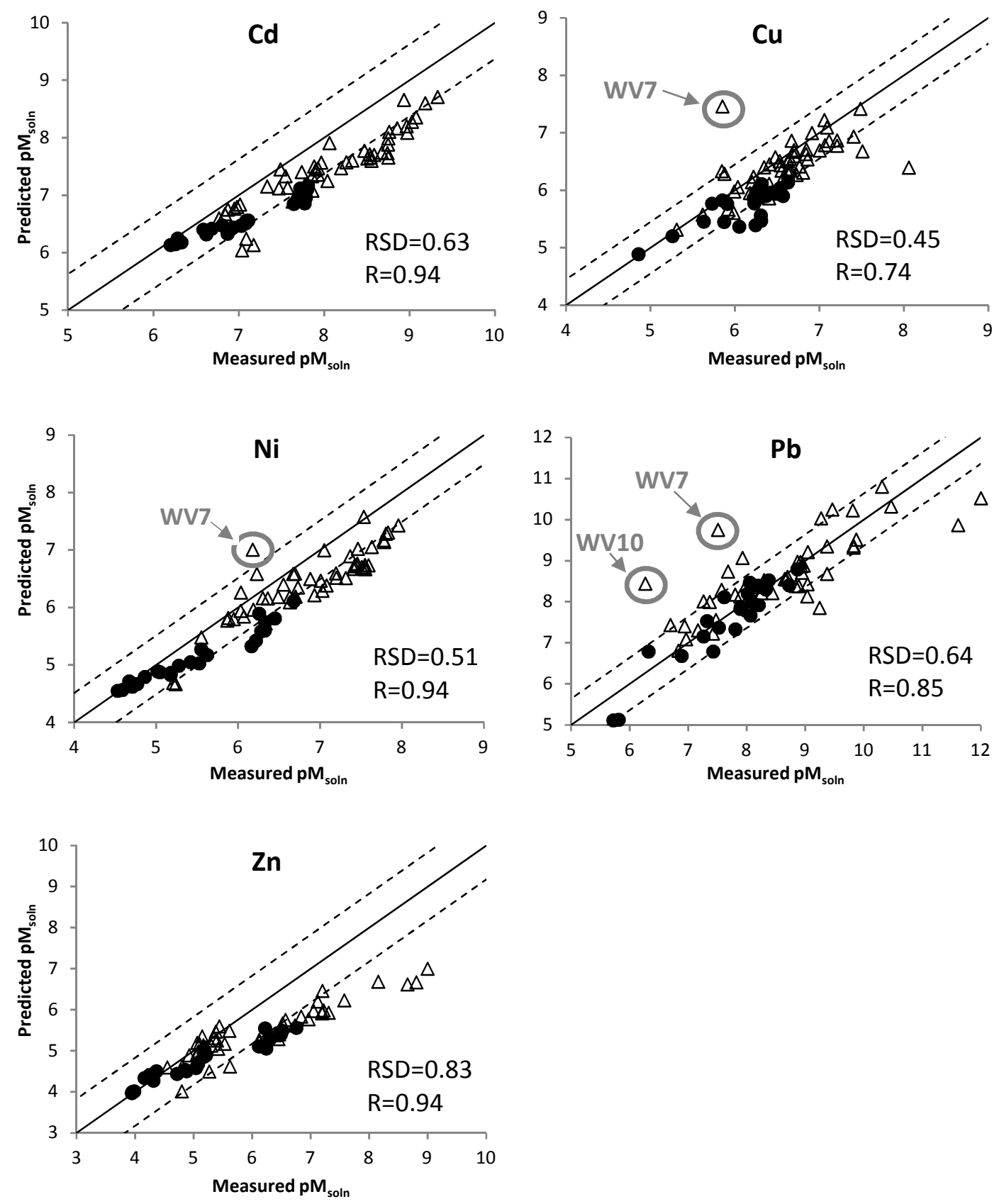

Figure 5: Solution concentrations $\left(\mathrm{pM}_{\mathrm{soln}}=-\log _{10}\left(\mathrm{M}_{\mathrm{soln}}\right)\right)$ of $\mathrm{Cd}, \mathrm{Cu}, \mathrm{Ni}, \mathrm{Pb}$ and $\mathrm{Zn}$ predicted by WHAM-VII against measured values for $\mathrm{MA}(\bullet)$ and Urban $(\Delta)$ soils suspended in $0.01 \mathrm{M} \mathrm{Ca}\left(\mathrm{NO}_{3}\right)_{2}$ (1 g: $30 \mathrm{~mL}) . \quad M_{E}$ was used as the input variable for reactive metal concentration. The solid line represents the 1:1 relation, and the dashed lines represent \pm 1 RSD for the model. Values of RSD and correlation coefficients $(r)$ are also shown. 

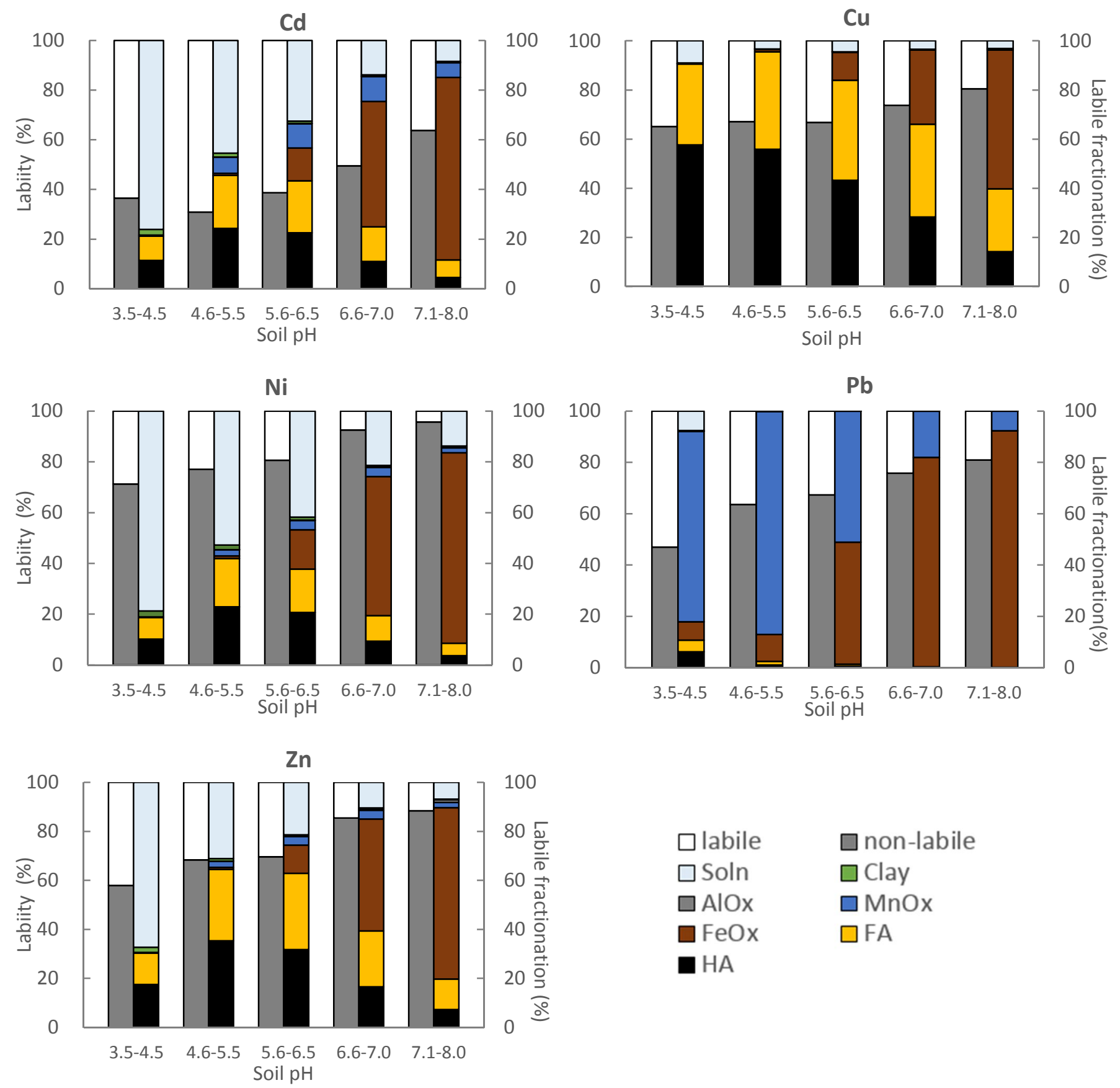

$\begin{array}{ll}\square \text { labile } & \square \text { non-labile } \\ \square \text { Soln } & \square \text { Clay } \\ \square \text { AlOx } & \square \mathrm{MnOx} \\ \square \text { FeOx } & \square \text { FA } \\ \square \text { HA } & \end{array}$

Figure 6: The first column shows fractionation by isotopic exchange into labile and non-labile metal $(\mathrm{Cd}, \mathrm{Cu}, \mathrm{Ni}, \mathrm{Pb}$ and $\mathrm{Zn})$ as a \% of total soil metal content in MA ( $n=23)$ and Urban $(n=50)$ soils, grouped by $\mathrm{pH}$ class. The second column shows the predicted distribution of the labile metal, only, between particulate humic and fulvic acid ( $\mathrm{HA}$ and $\mathrm{FA}$ ), $\mathrm{Fe}, \mathrm{Mn}$ and $\mathrm{Al}$ oxides (FeOx, MnOx and $A(O x)$, clays and the solution phase (Soln). Fractionation of labile metal was predicted using WHAM-VII parameterized using $\mathrm{M}_{\mathrm{E}}$ as input (Appendix 1). 
Appendix 1: Summary of the variables, parameters and settings for WHAM-VII modelling of trace metal solution concentration, speciation and fractionation.

\begin{tabular}{|c|c|}
\hline Variable & Settings \\
\hline \multicolumn{2}{|l|}{ Suspension condition } \\
\hline Suspended particulate matter (SPM) & $33.33 \mathrm{~g} \mathrm{~L}^{-1}$ \\
\hline Temperature $(\mathrm{K})$ & $288.15 \mathrm{~K}\left(15^{\circ} \mathrm{C}\right)$ \\
\hline $\mathrm{PCO}_{2}(\mathrm{~atm})$ & Measured bicarbonate concentration (DIC) \\
\hline Soil pH & Measured in $0.01 \mathrm{M} \mathrm{Ca}\left(\mathrm{NO}_{3}\right)_{2}$ soil suspensions. \\
\hline Charge balance options & No charge balance imposed i.e. a fixed (measured) $\mathrm{pH}$ value was usec \\
\hline \multicolumn{2}{|l|}{ Adsorption phase ( $\left.\mathrm{g} \mathrm{L}^{-1}\right)$} \\
\hline \multirow[t]{2}{*}{ Clay content } & MA soils: estimated from soil texture \\
\hline & Urban soils: measured by laser granulometry \\
\hline $\mathrm{Fe}, \mathrm{Al}$ and $\mathrm{Mn}$ oxides & DCB extraction; converted to $\mathrm{Fe}_{2} \mathrm{O}_{3} \cdot \mathrm{H}_{2} \mathrm{O}, \mathrm{Al}_{2} \mathrm{O}_{3}$ and $\mathrm{MnO}_{2}$ \\
\hline Humic and fulvic acid & Measured by alkaline extraction \\
\hline Colloidal fulvic acid & Estimated from measured DOC \\
\hline \multicolumn{2}{|c|}{ Major cation and anion concentration (mol $\left.L^{-1}\right)$} \\
\hline Dissolved major cations & Concentration in filtered soil suspensions $\left(0.01 \mathrm{M} \mathrm{Ca}\left(\mathrm{NO}_{3}\right)_{2}\right)$ \\
\hline$(\mathrm{Na}, \mathrm{Mg}, \mathrm{Al}, \mathrm{K}$ and $\mathrm{Ca})$ & $\begin{array}{l}\text { Precipitation option for } \mathrm{Al} \text { : One mole of precipitated } \mathrm{Al}(\mathrm{OH})_{3} \text { forms } 87 \\
\mathrm{~g} \text { of the binding phase within the particulate soil phase. }\end{array}$ \\
\hline $\mathrm{Fe}^{3+}$ activity & $\begin{array}{l}\text { Precipitation option for } \mathrm{Fe} \text { : assumes that } \mathrm{Fe}^{3+} \text { activity is controlled by } \\
\mathrm{Fe}(\mathrm{III})(\mathrm{OH})_{3} \text { solubility, calculated within the model. }\end{array}$ \\
\hline Dissolved nitrate $\left(\mathrm{NO}_{3}^{-}\right)$ & Solution concentration estimated as $0.02 \mathrm{M}$ in the suspension \\
\hline Total dissolved carbonate (all species) & Estimated from total inorganic carbon measured in solution \\
\hline \multicolumn{2}{|c|}{ Trace reactive metal concentration in soil suspension $\left(\operatorname{mol~L} L^{-1}\right)$} \\
\hline Total concentration & Estimated from E-values $\left(\mathrm{ME}_{\mathrm{E}}\right)$ \\
\hline \multicolumn{2}{|l|}{$\mathrm{Ni}, \mathrm{Cu}, \mathrm{Zn}, \mathrm{Cd}$ and $\mathrm{Pb}$} \\
\hline \multicolumn{2}{|l|}{ Other settings } \\
\hline Activity coefficient correction & Debye-Hückel \\
\hline WHAM parameter data sets & Default master, solute and binding phase data bases. \\
\hline
\end{tabular}


Appendix 2 a): Summary of soil properties and total $\mathrm{Ni}, \mathrm{Cu}, \mathrm{Zn}, \mathrm{Cd}$ and $\mathrm{Pb}$ concentration following metal amendment in $\mathrm{MA}$ soils.

\begin{tabular}{|c|c|c|c|c|c|c|c|c|c|c|c|c|}
\hline Soil series* & $\mathrm{pH}$ & $\begin{array}{c}\text { SOC } \\
\% \\
\end{array}$ & $\begin{array}{l}\text { FeOx } \\
\mathrm{g} \mathrm{kg}^{-1}\end{array}$ & $\begin{array}{c}\text { MnOx } \\
\mathrm{g} \mathrm{kg}^{-1}\end{array}$ & $\begin{array}{l}\text { AlOx } \\
\mathrm{g} \mathrm{kg}^{-1}\end{array}$ & $\begin{array}{c}\text { Clay } \\
\% \\
\end{array}$ & $\begin{array}{l}\text { Total Ni } \\
\mathrm{mg} \mathrm{kg}^{-1}\end{array}$ & $\begin{array}{c}\text { Total Cu } \\
\mathrm{mg} \mathrm{kg}^{-1}\end{array}$ & $\begin{array}{c}\text { Total Zn } \\
\mathrm{mg} \mathrm{kg}^{-1}\end{array}$ & $\begin{array}{c}\text { Total Cd } \\
\mathrm{mg} \mathrm{kg}^{-1}\end{array}$ & $\begin{array}{c}\text { Total Pb } \\
\mathrm{mg} \mathrm{kg}^{-1}\end{array}$ & $\begin{array}{l}\text { DOC* } \\
\mathrm{mg} \mathrm{L}^{-1}\end{array}$ \\
\hline Bardsey & 3.57 & 3.18 & 19.9 & 0.16 & 1.44 & 35.0 & 69.6 & 134 & 273 & 2.5 & 343 & 48.1 \\
\hline Wick & 3.76 & 4.47 & 17.9 & 0.22 & 1.26 & 10.0 & 82.1 & 158 & 327 & 2.7 & 346 & 58.1 \\
\hline Iveshead & 3.79 & 6.55 & 16.3 & 0.20 & 2.99 & 5.0 & 73.8 & 147 & 328 & 3.1 & 345 & 46.0 \\
\hline Pwelliperian & 4.69 & 3.03 & 14.6 & 0.47 & 3.44 & 35.0 & 97.7 & 161 & 498 & 3.1 & 341 & 26.0 \\
\hline Rivington & 5.27 & 3.36 & 10.4 & 0.40 & 0.65 & 5.0 & 71.1 & 133 & 324 & 2.9 & 311 & 29.7 \\
\hline Braunshweig & 5.36 & 2.28 & 5.4 & 0.61 & 0.10 & 15.0 & 73.3 & 138 & 318 & 2.8 & 292 & 18.0 \\
\hline Woburn & 5.61 & 1.00 & 20.1 & 0.24 & 0.24 & 5.0 & 76.5 & 136 & 287 & 2.7 & 294 & 15.4 \\
\hline Fladbury & 5.67 & 4.66 & 24.8 & 0.86 & 0.94 & 70.0 & 111 & 155 & 385 & 3.3 & 328 & 21.9 \\
\hline Ticknall & 5.72 & 5.20 & 20.9 & 0.48 & 1.76 & 15.0 & 86.9 & 150 & 437 & 3.0 & 572 & 16.6 \\
\hline Cottam & 5.76 & 2.08 & 15.6 & 0.61 & 0.67 & 15.0 & 92.1 & 161 & 365 & 3.5 & 332 & 12.9 \\
\hline Rosemaund & 5.84 & 1.86 & 10.8 & 0.74 & 0.56 & 35.0 & 124 & 153 & 351 & 2.9 & 297 & 9.9 \\
\hline Arrow & 6.06 & 2.08 & 15.9 & 0.57 & 0.64 & 10.0 & 83.1 & 156 & 347 & 3.2 & 323 & 10.3 \\
\hline Watlington & 6.11 & 1.24 & 18.2 & 0.81 & 0.22 & 10.0 & 88.5 & 146 & 335 & 3.1 & 304 & 13.1 \\
\hline Insch & 6.20 & 4.13 & 27.4 & 0.78 & 7.38 & 17.5 & 79.2 & 140 & 293 & 2.8 & 268 & 29.4 \\
\hline Newport & 6.31 & 1.03 & 15.8 & 0.51 & 0.55 & 10.0 & 83.3 & 157 & 350 & 2.9 & 314 & 13.5 \\
\hline Gleadthorpe & 6.45 & 1.68 & 8.8 & 0.35 & 0.41 & 10.0 & 75.2 & 145 & 341 & 3.0 & 306 & 13.8 \\
\hline Denchworth & 6.78 & 4.42 & 18.9 & 0.77 & 1.07 & 70.0 & 98.0 & 155 & 316 & 2.8 & 300 & 10.8 \\
\hline Ragdale & 6.78 & 4.10 & 29.8 & 0.79 & 1.60 & 35.0 & 107 & 154 & 404 & 3.3 & 321 & 13.3 \\
\hline Bridgets & 6.91 & 2.38 & 28.7 & 2.68 & 3.01 & 35.0 & 108 & 142 & 377 & 4.3 & 306 & 7.1 \\
\hline Marian & 6.95 & 7.06 & 15.8 & 2.54 & 0.15 & 35.0 & 93.6 & 172 & 417 & 3.2 & 377 & 16.3 \\
\hline Worcester & 7.08 & 2.88 & 15.4 & 0.79 & 0.00 & 35.0 & 124 & 166 & 436 & 3.3 & 339 & 5.2 \\
\hline Hanslope & 7.08 & 4.39 & 27.6 & 0.77 & 1.41 & 35.0 & 93.6 & 139 & 360 & 2.9 & 285 & 16.2 \\
\hline Evesham & 7.12 & 2.38 & 22.0 & 0.98 & 1.11 & 70.0 & 97.6 & 155 & 337 & 3.0 & 312 & 7.6 \\
\hline
\end{tabular}

*Soil Survey of England and Wales classification of soil series.

**DOC determined in suspension ( $1 \mathrm{~g}$ soil: $30 \mathrm{~mL}$ water). 
Appendix 2 b): Summary of soil properties, sampling location, land use and total $\mathrm{Ni}, \mathrm{Cu}, \mathrm{Zn}, \mathrm{Cd}$ and Pb concentration in Urban soils (Wolverhampton).

\begin{tabular}{|c|c|c|c|c|c|c|c|c|c|c|c|c|c|c|}
\hline Sample & $\mathrm{pH}$ & $\begin{array}{c}\text { SOC } \\
\% \\
\end{array}$ & $\begin{array}{l}\text { FeOx } \\
\mathrm{g} \mathrm{kg}^{-1}\end{array}$ & $\begin{array}{c}\text { MnOx } \\
\mathrm{g} \mathrm{kg}^{-1}\end{array}$ & $\begin{array}{l}\text { AlOx } \\
\mathrm{g} \mathrm{kg}^{-1}\end{array}$ & $\begin{array}{c}\text { Clay } \\
\% \\
\end{array}$ & $\begin{array}{l}\text { Total Ni } \\
\mathrm{mg} \mathrm{kg}^{-1}\end{array}$ & $\begin{array}{c}\text { Total } \mathrm{Cu} \\
\mathrm{mg} \mathrm{kg}^{-1}\end{array}$ & $\begin{array}{l}\text { Total Zn } \\
\mathrm{mg} \mathrm{kg}^{-1}\end{array}$ & $\begin{array}{c}\text { Total Cd } \\
\mathrm{mg} \mathrm{kg}^{-1}\end{array}$ & $\begin{array}{c}\text { Total Pb } \\
\mathrm{mg} \mathrm{kg}^{-1}\end{array}$ & $\begin{array}{l}\text { DOC* } \\
\mathrm{mg} \mathrm{L}^{-1}\end{array}$ & Grid Ref. & Landuse \\
\hline WV1 & 4.63 & 3.43 & 8.4 & 0.24 & 0.81 & 20.4 & 18.3 & 35.4 & 134 & 0.4 & 56.7 & 35.8 & 391030301170 & Grassland (golfcourse) \\
\hline WV2 & 3.92 & 2.81 & 9.7 & 0.44 & 1.08 & 22.5 & 12.1 & 19.4 & 61.5 & 0.3 & 53.2 & 40.6 & 388450300860 & Grassland (golfcourse) \\
\hline WV3 & 6.11 & 10.99 & 18.2 & 1.26 & 1.59 & 15.7 & 55.3 & 403 & 1050 & 3.7 & 266 & 59.4 & 393690297700 & Park \\
\hline WV4 & 5.87 & 3.35 & 13.8 & 0.46 & 1.07 & 19.8 & 22.9 & 69.1 & 313 & 0.6 & 109 & 23.0 & 392180297280 & Grassland (open land) \\
\hline WV5 & 6.46 & 13.28 & 26.3 & 0.84 & 1.16 & 14.6 & 77.9 & 233 & 588 & 1.3 & 227 & 8.0 & 393730296530 & Old industrial (gas works) \\
\hline WV6 & 6.84 & 9.81 & 38.5 & 1.52 & 2.50 & 18.6 & 300 & 2200 & 4170 & 26.1 & 746 & 8.0 & 394490295160 & Wasteland (old landfill) \\
\hline WV7 & 7.41 & 5.40 & 23.1 & 0.67 & 0.88 & 16.9 & 83.3 & 493 & 1170 & 3.6 & 590 & 3.2 & 394960295960 & Grassland \\
\hline WV8 & 5.64 & 10.07 & 19.7 & 0.92 & 4.47 & 16.4 & 57.4 & 158 & 553 & 2.1 & 358 & 17.7 & 397060296980 & Woodland \\
\hline WV9 & 5.56 & 4.39 & 16.8 & 0.62 & 1.66 & 18.4 & 32.3 & 134 & 300 & 0.9 & 273 & 17.5 & 390170301290 & Grassland \\
\hline WV10 & 7.07 & 8.01 & 19.9 & 0.84 & 0.94 & 18.3 & 66.9 & 298 & 1100 & 4.1 & 1050 & 9.7 & 391330301090 & Old industrial (tyre factory) \\
\hline WV11 & 4.46 & 3.68 & 14.9 & 0.38 & 1.80 & 22.9 & 25.3 & 87.7 & 514 & 1.9 & 173 & 28.9 & 390810296710 & Domestic garden \\
\hline WV12 & 5.79 & 2.73 & 11.1 & 0.51 & 0.75 & 18.9 & 15.0 & 30.4 & 270 & 0.7 & 199 & 22.9 & 388240295750 & Grassland \\
\hline WV13 & 5.54 & 3.83 & 12.6 & 0.64 & 0.71 & 24.4 & 25.4 & 51.1 & 308 & 1.0 & 131 & 22.1 & 392760295760 & Park \\
\hline WV14 & 5.22 & 25.08 & 20.3 & 0.55 & 0.68 & 5.1 & 58.4 & 265 & 1190 & 5.1 & 332 & 16.2 & 392830299710 & Nature reserve (railway) \\
\hline WV15 & 7.12 & 11.17 & 19.2 & 3.01 & 0.55 & 11.8 & 47.6 & 101 & 290 & 1.1 & 140 & 24.7 & 388910299580 & Nature reserve (railway) \\
\hline WV16 & 4.01 & 14.46 & 7.1 & 0.27 & 5.10 & 16.8 & 29.1 & 89.1 & 135 & 0.7 & 88.4 & 18.0 & 392380295460 & Vegetated colliery spoil heap \\
\hline WV17 & 5.64 & 2.76 & 11.1 & 0.52 & 0.87 & 19.4 & 26.9 & 73.8 & 239 & 0.6 & 141 & 50.3 & 391240297580 & Old industrial (disused factory) \\
\hline WV18 & 4.63 & 5.49 & 16.7 & 0.51 & 2.49 & 22.6 & 39.8 & 204 & 524 & 1.7 & 150 & 26.3 & 395120299290 & Grassland (not maintained) \\
\hline WV19 & 5.37 & 5.19 & 12.6 & 0.41 & 0.01 & 19.1 & 45.8 & 58.7 & 192 & 0.5 & 48.7 & 11.6 & 395150299140 & Grassland \\
\hline WV20 & 4.14 & 4.54 & 10.8 & 0.25 & 2.36 & 15.3 & 15.1 & 77.6 & 105 & 0.5 & 85.7 & 30.4 & 396720301130 & Grassland \\
\hline WV21 & 6.41 & 2.85 & 13.5 & 0.48 & 0.00 & 24.0 & 54.5 & 48.7 & 102 & 0.2 & 31.9 & 7.8 & 393960299860 & Brownfield \\
\hline WV22 & 8.08 & 2.50 & 12.3 & 0.35 & 0.00 & 21.3 & 43.1 & 90.0 & 154 & 0.3 & 45.9 & 7.3 & 394390299860 & Brownfield \\
\hline WV23 & 7.63 & 1.37 & 12.8 & 0.29 & 0.02 & 19.0 & 65.6 & 79.0 & 267 & 0.7 & 78.8 & 19.4 & 395400299670 & Brownfield \\
\hline WV24 & 7.22 & 2.64 & 14.1 & 0.45 & 0.43 & 21.1 & 33.6 & 82.3 & 605 & 1.2 & 351 & 12.3 & 394680299830 & Brownfield \\
\hline WV25 & 4.05 & 11.36 & 20.1 & 0.70 & 3.84 & 13.8 & 55.2 & 188 & 356 & 1.8 & 217 & 20.7 & 394210298970 & Grassland (park) \\
\hline WV26 & 6.60 & 2.70 & 9.9 & 0.28 & 0.00 & 20.6 & 20.0 & 52.6 & 133 & 0.5 & 63.3 & 23.2 & 394600298750 & Grassland \\
\hline WV27 & 7.67 & 3.16 & 28.7 & 0.54 & 0.29 & 20.5 & 39.1 & 160 & 279 & 0.6 & 177 & 15.3 & 392800298520 & Brownfield \\
\hline WV28 & 7.25 & 5.85 & 21.1 & 0.44 & 0.66 & 18.8 & 44.8 & 150 & 281 & 0.6 & 156 & 10.6 & 391700310630 & Brownfield \\
\hline WV29 & 6.87 & 20.50 & 27.4 & 1.03 & 0.64 & 20.0 & 94.1 & 338 & 739 & 3.3 & 429 & 10.4 & 391680300080 & Deciduous woodland \\
\hline WV30 & 6.32 & 3.60 & 13.5 & 0.34 & 0.26 & 18.6 & 24.0 & 82.3 & 158 & 0.6 & 109 & 18.3 & 391780300120 & Grassland (park) \\
\hline
\end{tabular}


Appendix 2 c): Summary of soil properties, sampling location, land use and total $\mathrm{Ni}, \mathrm{Cu}, \mathrm{Zn}, \mathrm{Cd}$ and $\mathrm{Pb}$ concentration in Urban soils (Nottingham).

\begin{tabular}{|c|c|c|c|c|c|c|c|c|c|c|c|c|c|c|}
\hline Sample & pH & $\begin{array}{c}\text { SOC } \\
\%\end{array}$ & $\begin{array}{l}\text { FeOx } \\
\mathrm{g} \mathrm{kg}^{-1}\end{array}$ & $\begin{array}{l}\text { MnOx } \\
\mathrm{g} \mathrm{kg}^{-1}\end{array}$ & $\begin{array}{l}\text { AlOx } \\
\mathrm{g} \mathrm{kg}^{-1}\end{array}$ & $\begin{array}{c}\text { Clay } \\
\%\end{array}$ & $\begin{array}{l}\text { Total Ni } \\
\mathrm{mg} \mathrm{kg}^{-1}\end{array}$ & $\begin{array}{l}\text { Total } \mathrm{Cu} \\
\mathrm{mg} \mathrm{kg}^{-1}\end{array}$ & $\begin{array}{c}\text { Total Zn } \\
\mathrm{mg} \mathrm{kg}^{-1}\end{array}$ & $\begin{array}{l}\text { Total Cd } \\
\mathrm{mg} \mathrm{kg}^{-1}\end{array}$ & $\begin{array}{l}\text { Total Pb } \\
\mathrm{mg} \mathrm{kg}^{-1}\end{array}$ & $\begin{array}{l}\text { DOC* } \\
\mathrm{mg} \mathrm{L}^{-1}\end{array}$ & Grid Ref. & Landuse \\
\hline NG1 & 4.75 & 5.00 & 40.6 & 1.67 & 3.81 & 24.6 & 49.5 & 51.4 & 340 & 1.8 & 194 & 29.9 & 455470336660 & Grassland (football field) \\
\hline NG2 & 5.52 & 4.77 & 14.9 & 0.86 & 2.33 & 28.7 & 24.4 & 50.0 & 229 & 1.1 & 412 & 18.6 & 455280338770 & Churchyard \\
\hline NG3 & 6.47 & 5.10 & 34.4 & 1.14 & 1.60 & 21.4 & 44.1 & 26.5 & 111 & 0.3 & 60.9 & 29.1 & 453760341550 & School \\
\hline NG4 & 6.29 & 5.25 & 18.8 & 0.49 & 1.24 & 18.3 & 37.1 & 224 & 881 & 2.5 & 1300 & 7.0 & 454700343720 & Domestic garden \\
\hline NG5 & 6.99 & 3.26 & 14.6 & 0.47 & 0.38 & 20.1 & 31.6 & 57.9 & 439 & 1.1 & 353 & 14.6 & 457360342370 & Domestic garden \\
\hline NG6 & 6.78 & 10.70 & 39.5 & 0.81 & 1.36 & 19.8 & 60.1 & 161 & 459 & 2.0 & 406 & 14.6 & 458720339210 & Railway \\
\hline NG7 & 7.00 & 5.31 & 21.4 & 0.85 & 0.88 & 18.8 & 59.0 & 129 & 359 & 1.5 & 385 & 13.0 & 458500339110 & Grassland (imported) \\
\hline NG8 & 4.15 & 7.90 & 38.2 & 1.32 & 4.52 & 18.0 & 62.6 & 65.2 & 374 & 1.6 & 352 & 63.5 & 459710339170 & Grassland (racecourse) \\
\hline NG9 & 6.27 & 4.81 & 14.6 & 0.38 & 1.50 & 20.5 & 28.2 & 47.6 & 169 & 0.6 & 205 & 14.5 & 453570344310 & Vegetated colliery spoil heap \\
\hline NG10 & 6.53 & 5.21 & 18.5 & 0.79 & 1.38 & 21.7 & 35.2 & 54.4 & 301 & 0.8 & 257 & 11.7 & 455170342480 & Vegetated colliery spoil heap \\
\hline NG11 & 7.25 & 8.56 & 25.3 & 1.30 & 1.83 & 14.8 & 228 & 1260 & 1690 & 2.1 & 1110 & 6.4 & 455770338590 & Disused factory \\
\hline NG12 & 7.38 & 13.49 & 43.0 & 2.31 & 3.32 & 12.1 & 380 & 3190 & 2520 & 5.6 & 1240 & 6.9 & 455760338550 & Disused factory \\
\hline NG13 & 7.02 & 1.28 & 15.6 & 0.35 & 0.03 & 20.7 & 20.3 & 26.0 & 26.0 & 0.1 & 18.5 & 8.0 & 453570344210 & Grassland (amenity) \\
\hline NG14 & 6.54 & 11.41 & 16.7 & 0.59 & 3.59 & 13.0 & 370 & 644 & 1740 & 38.2 & 600 & 22.4 & 464120340530 & Sewage Farm \\
\hline NG15 & 5.99 & 6.86 & 15.5 & 0.30 & 2.79 & 20.7 & 199 & 382 & 1020 & 19.2 & 337 & 21.1 & 464130340810 & Sewage Farm \\
\hline NG16 & 7.57 & 5.03 & 25.0 & 0.93 & 0.61 & 18.9 & 44.0 & 92.9 & 223 & 0.9 & 121 & 7.3 & 462830340800 & Brownfield \\
\hline NG17 & 6.34 & 18.25 & 27.7 & 1.06 & 1.33 & 11.6 & 99.0 & 274 & 634 & 1.1 & 1410 & 16.9 & 462770340730 & Brownfield \\
\hline NG18 & 6.78 & 3.35 & 22.2 & 1.13 & 0.60 & 20.1 & 43.7 & 35.7 & 216 & 1.4 & 79.2 & 11.2 & 462900340700 & Brownfield \\
\hline NG19 & 6.93 & 2.98 & 34.8 & 1.43 & 2.19 & 18.7 & 32.3 & 31.7 & 132 & 0.4 & 65.9 & 12.3 & 446800339730 & Brownfield \\
\hline NG20 & 6.68 & 3.00 & 31.0 & 0.70 & 1.01 & 24.0 & 32.2 & 52.9 & 299 & 0.7 & 90.0 & 19.6 & 447040339240 & Brownfield \\
\hline
\end{tabular}


Appendix 3: Average difference between $\% M_{E}$ and $\% M_{E r}\left(\Delta M_{E}\right), R S D, R^{2}, p$-values for correlations between \% $M_{E}$ and \%M and standard error of the mean for replicate estimates of $\% \mathrm{ME}_{\mathrm{E}}$ and $\% \mathrm{M}_{\mathrm{Er}}$.

\begin{tabular}{cccccc}
\hline & $\mathbf{N i}$ & $\mathbf{C u}$ & $\mathrm{Zn}$ & $\mathbf{C d}$ & $\mathbf{P b}$ \\
\hline$\Delta \mathrm{M}_{\mathrm{E}}$ & -0.14 & 1.76 & -0.52 & -0.35 & -1.59 \\
$\mathrm{RSD}$ & 0.79 & 4.84 & 28.22 & 0.13 & 15.49 \\
$\mathrm{r}$ & 0.999 & 0.997 & 0.973 & 0.997 & 0.963 \\
$\mathrm{p}-\mathrm{value}$ & $>0.05$ & $<0.01$ & $>0.05$ & $>0.05$ & $>0.05$ \\
SE\%ME & 0.371 & 0.873 & 1.218 & 2.167 & 1.216 \\
SE\%MEr & 0.468 & 0.666 & 0.636 & 1.189 & 1.854 \\
\hline
\end{tabular}

Appendix 4: Linear regression model coefficients, RSD and $r$ values for model prediction of \% $\mathrm{M}_{\mathrm{E}}$. The regression (see Eq. 3) was parameterized from $\% \mathrm{M}_{\mathrm{E}}\left(\mathrm{mg} \mathrm{kg}^{-1}\right)$ measured on $\mathrm{MA}$ soils. Values in brackets are the \% of total variance, n.s = not significant .

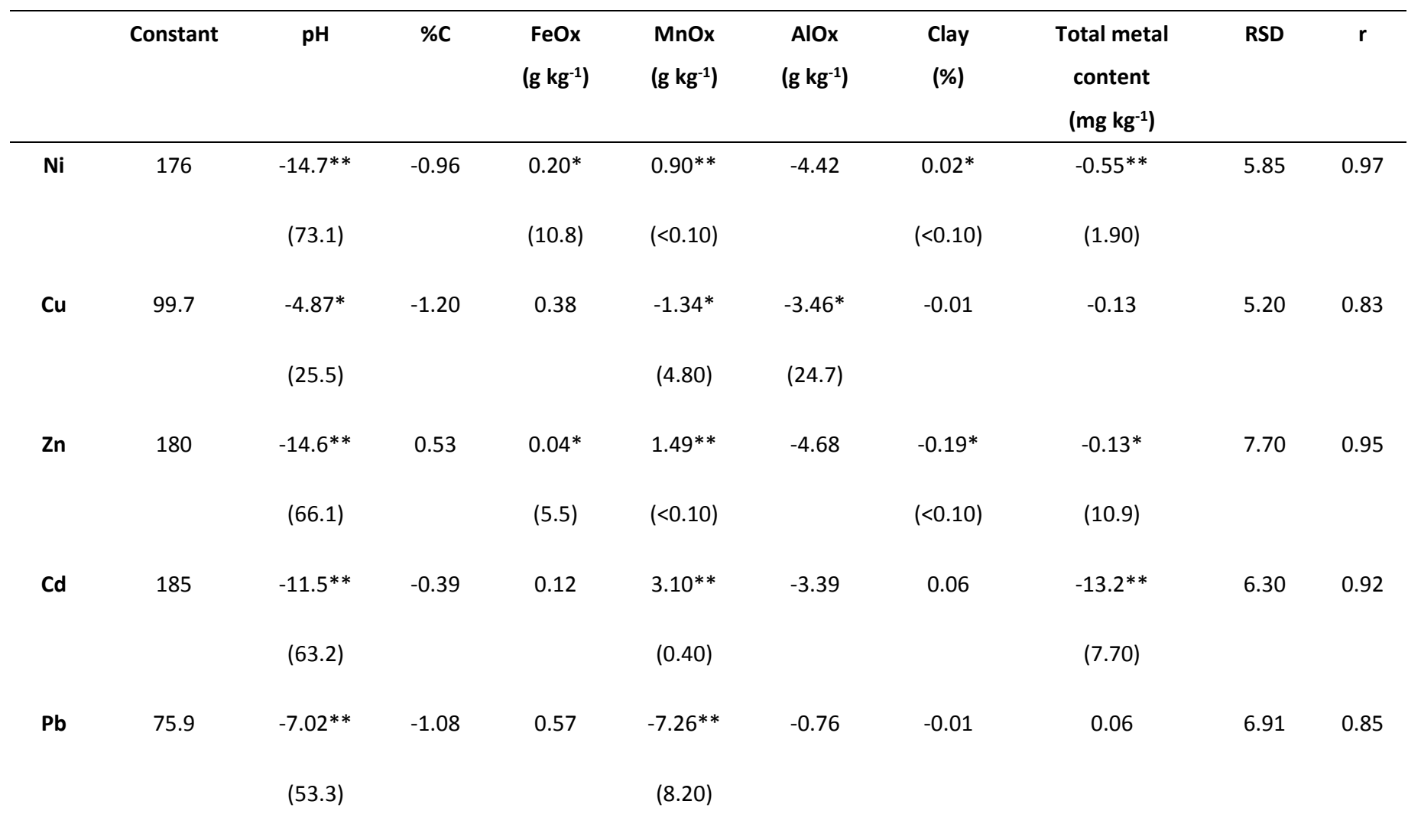

** significant $(\mathrm{p}<0.01),{ }^{*}$ significant $(\mathrm{p}<0.05)$ 
Appendix 5: Values of model parameters $\left(\mathrm{pH}_{50}, \mathrm{k}_{\mathrm{M}}, \mathrm{n}\right), \mathrm{RSD}, \mathrm{r}$ values and $\triangle \% \mathrm{M}_{\mathrm{E}}$ (average deviation of predicted $\% \mathrm{M}_{\mathrm{E}}$ from measured value) from sigmoidal model prediction of \%E-value using Eq. 4 and Eq. 5 applied to MA soils only. The values in bold italic are the best fit of the measured $\% \mathrm{M}_{\mathrm{E}}$.

\begin{tabular}{|c|c|c|c|c|c|c|}
\hline & & $\mathrm{Ni}$ & $\mathrm{Cu}$ & $\mathrm{Zn}$ & $\mathrm{Cd}$ & $\mathrm{Pb}$ \\
\hline \multicolumn{7}{|l|}{ Equation 4: } \\
\hline & $\mathrm{pH}_{50}$ & 5.06 & 5.55 & 5.36 & 7.89 & 6.33 \\
\hline & $\mathbf{k}_{\mathrm{M}}$ & 0.76 & 0.16 & 0.72 & 0.66 & 0.35 \\
\hline & RSD & 11.5 & 7.59 & 13.2 & 8.73 & 8.97 \\
\hline & $r$ & 0.85 & 0.51 & 0.81 & 0.77 & 0.72 \\
\hline & $\Delta \% \mathrm{M}_{\mathrm{E}}$ & -0.39 & -0.01 & 0.01 & 0.13 & 0.12 \\
\hline \multicolumn{7}{|l|}{ Equation 5: } \\
\hline \multirow[t]{6}{*}{$\mathrm{pH}+\% \mathrm{SOC}$} & $\mathrm{pH}_{50}$ & 4.94 & 5.17 & 5.02 & 7.59 & 6.27 \\
\hline & $\mathbf{k}_{\mathrm{M}}$ & 0.54 & 0.07 & 0.23 & 0.38 & 0.12 \\
\hline & $n$ & 0.28 & 0.57 & 0.95 & 0.86 & 0.86 \\
\hline & RSD & 11.2 & 7.66 & 13.3 & 11.5 & 8.53 \\
\hline & $r$ & 0.86 & 0.50 & 0.81 & 0.65 & 0.76 \\
\hline & $\Delta \% \mathrm{M}_{\mathrm{E}}$ & 0.18 & 0.66 & 1.43 & 0.37 & 0.74 \\
\hline \multirow[t]{6}{*}{$\mathrm{pH}+\mathrm{Ox}$} & $\mathrm{pH}_{50}$ & 4.99 & 5.47 & 5.29 & 8.03 & 6.40 \\
\hline & $k_{M}$ & 0.16 & 0.06 & 0.12 & 1.19 & 0.13 \\
\hline & $n$ & 0.83 & 0.57 & 0.95 & -0.40 & 0.55 \\
\hline & RSD & 10.4 & 7.45 & 12.3 & 8.06 & 8.80 \\
\hline & $r$ & 0.88 & 0.53 & 0.84 & 0.81 & 0.73 \\
\hline & $\Delta \% \mathrm{M}_{\mathrm{E}}$ & 0.15 & 0.40 & 1.08 & 0.06 & -0.02 \\
\hline \multirow[t]{6}{*}{ pH + \%Clay } & $\mathrm{pH}_{50}$ & 5.01 & 5.70 & 5.16 & 7.22 & 6.46 \\
\hline & $k_{M}$ & 0.20 & 0.03 & 0.03 & 0.10 & 0.02 \\
\hline & $n$ & 0.41 & 0.57 & 0.95 & 0.86 & 0.86 \\
\hline & RSD & 10.0 & 7.17 & 14.5 & 11.8 & 11.4 \\
\hline & $r$ & 0.89 & 0.58 & 0.77 & 0.65 & 0.51 \\
\hline & $\Delta \% \mathrm{M}_{\mathrm{E}}$ & 1.05 & 0.12 & 2.75 & 0.19 & 2.04 \\
\hline
\end{tabular}

Appendix 6: Summary of model outcomes comparing predicted and measured solution concentrations of $\mathrm{Ni}, \mathrm{Cu}, \mathrm{Zn}$, $\mathrm{Cd}$ and $\mathrm{Pb}$ using E-values ( $\mathrm{M}_{\mathrm{E}}$ ) as input variables to WHAM-VII (Appendix 1; Fig. 5).

\begin{tabular}{cccccc}
\hline & $\mathrm{Ni}$ & $\mathrm{Cu}$ & $\mathrm{Zn}$ & $\mathrm{Cd}$ & $\mathrm{Pb}$ \\
\hline $\mathrm{RSD}$ & 0.51 & 0.45 & 0.83 & 0.63 & 0.64 \\
$\mathbf{r}$ & 0.94 & 0.74 & 0.94 & 0.94 & 0.85 \\
slope & 0.40 & 0.23 & 0.58 & 0.56 & -0.02 \\
intercept & 0.82 & 0.73 & 0.54 & 0.78 & 0.80 \\
\hline
\end{tabular}


Appendix 7 a): Correlation $(r)$ between $\Delta \mathrm{pM}_{\text {soln }}$ (the bias between measured and modelled solubility by WHAM on a -log scale) and soil pH or percentage binding with an important particulate phase (FeOx, $\mathrm{MnOx}$, AlOx, HA) or colloidal (dissolved) phase (FA).

\begin{tabular}{cccccc}
\hline $\mathbf{r}$ & $\mathbf{N i}$ & $\mathbf{C u}$ & $\mathbf{Z n}$ & $\mathbf{C d}$ & $\mathbf{P b}$ \\
\hline $\mathrm{pH}(\mathrm{p}<0.01)$ & 0.431 & 0.354 & 0.751 & 0.749 & \\
$\mathrm{FeOx}(\mathrm{p}<0.05)$ & 0.284 & & 0.744 & 0.532 \\
$\mathrm{MnOx}(\mathrm{p}<0.05)$ & 0.270 & 0.342 & & \\
$\mathrm{HA}(\mathrm{p}<0.05)$ & & -0.414 & & \\
Colloidal-FA & & & &
\end{tabular}

Appendix 7 b): Difference between measured and predicted Pb solubility ( $\triangle \mathrm{pPbsoln}$ ) as a function of (a) soil $\mathrm{pH}$ and fractional sorption by (b) FeOx and (c) MnOx.
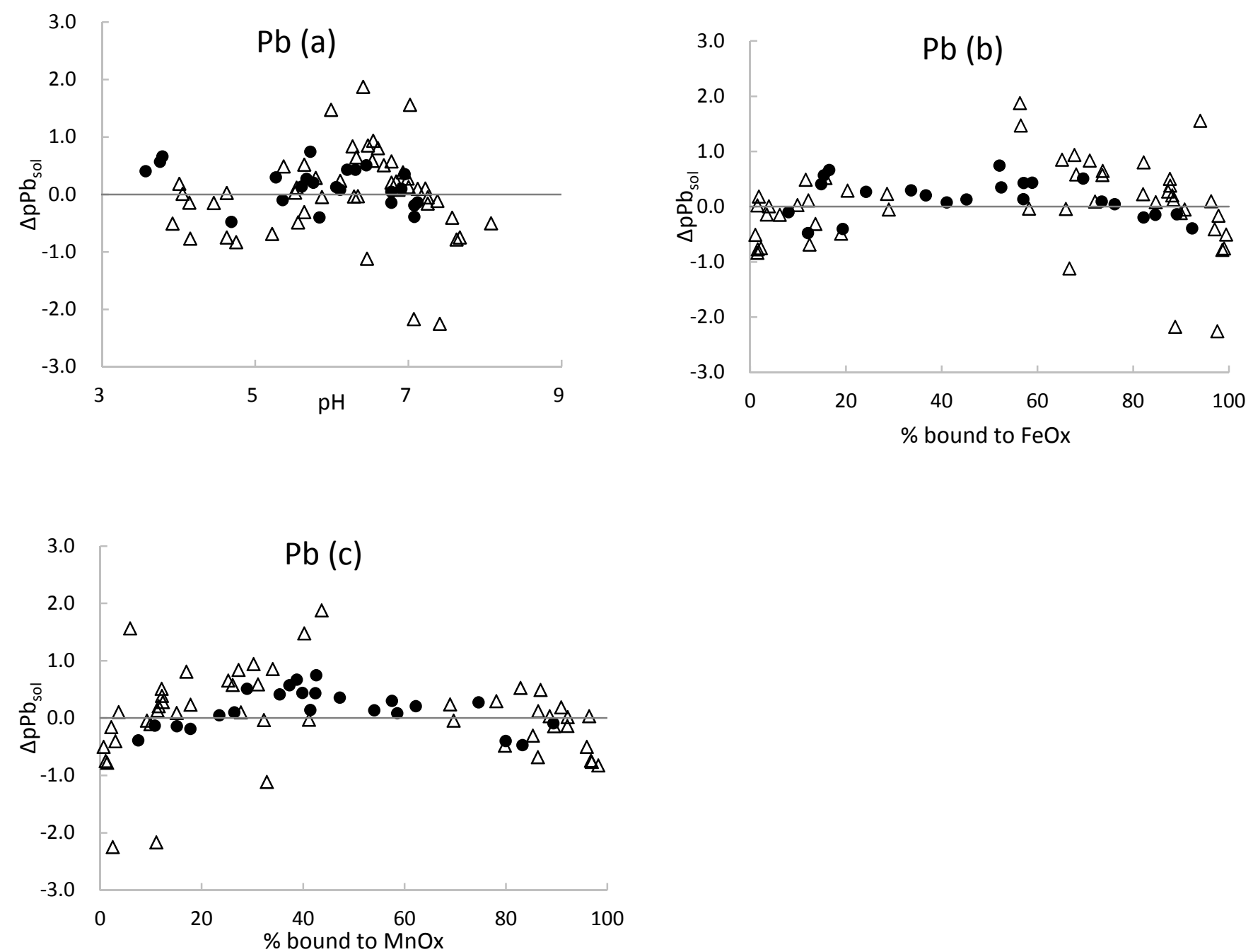